\title{
Designing New 5-Nitroimidazoles: Towards Safer Anti-infectious Agents
}

\author{
Maxime D. Crozet, Thierry Terme, Patrice Vanelle*
}

Aix-Marseille Univ, UMR CNRS 7273: Institut de Chimie Radicalaire, Equipe Pharmaco-Chimie Radicalaire (LPCR), Faculté de Pharmacie, 27 Boulevard Jean Moulin, CS 30064, 13385 Marseille cedex 5, France.

Fax: +33(4)86136822

E-mail: patrice.vanelle@univ-amu.fr

E-mail: maxime.crozet@univ-amu.fr

Dedicated to Dr Pascal GEORGE, President of The French Medicinal Chemistry Society (SCT).

\section{Pharmacological value of the nitroimidazole moiety}

\section{A. Introduction - Majorities}

The story of the nitroimidazole moiety from a pharmacological point of view began in 1953 with the study of a strain of Nocardia mesenterica from which the 2-nitroimidazole, called Azomycine, was extracted by Japanese researchers Maeda, Osato, Umezawa[1].This compound was studied in 1955 by Nakamura who determined its chemical structure[2] (Fig. 1).<smiles>O=[N+]([O-])c1ncc[nH]1</smiles>

Fig. (1).2-Nitroimidazole (AZOMYCINE ${ }^{\circledR}$ )

In 1956, both Horie [3] and Despois et al.[4] separately described the activity of azomycine on certain protozoa, especially Trichomonas vaginalis.

Today, the nitroimidazoles include a series of active substances useful in various fields, the position of the nitro group on the imidazole moiety defining their range of activity.2-Nitroimidazoles, especially benznidazole (RADANIL $^{\circledR}$ ) (Fig. 2), are known for their biological activity on Trypanosoma cruzi, [5] an agent of Chagas disease, and can also be of value in cancer research [6].<smiles>O=C(Cn1ccnc1[N+](=O)[O-])NCc1ccccc1</smiles>

Fig. (2).Benznidazole (RADANIL $\left.{ }^{\circledR}\right)$

4-Nitroimidazoles such as azathioprine (IMUREL ${ }^{\circledR}$ ) (Fig. 3), because of their immunosuppressive activity, are generally used to prevent rejection of transplanted organs and to treat autoimmune diseases[7]. They also 
showed an activity on the parasite agent of Chagas disease, Trypanosoma cruzi, in recent studies performed under the DNDi (Drug for Neglected Diseases initiative)[8].<smiles>Cn1cnc([N+](=O)[O-])c1Sc1ncnc2nc[nH]c12</smiles>

Fig. (3). Azathioprine (IMUREL ${ }^{\circledR}$ )

5-Nitroimidazoles are mainly known for their anti-infectious activity[9-13].Today, there are many medical applications for compounds containing the nitroimidazole moiety such as metronidazole (Fig. 4), which is the compound most widely used.<smiles>Cc1ncc([N+](=O)[O-])n1C</smiles>

Dimetridazole $\left(\right.$ EMTRYL $\left.^{\circledR}\right)$<smiles>Cc1ncc([N+](=O)[O-])n1CCO</smiles>

Metronidazole (FLAGYL ${ }^{\circledR}$ )<smiles>Cc1ncc([N+](=O)[O-])n1CC(C)O</smiles>

Secnidazole<smiles>CCS(=O)(=O)CCn1c([N+](=O)[O-])cnc1C</smiles>

Tinidazole (FASIGYNE ${ }^{\circledR}$ )<smiles>Cc1ncc([N+](=O)[O-])n1CC(O)CCl</smiles>

Ornidazole (TIBERAL ${ }^{\circledR}$ )<smiles>Cn1c([N+](=O)[O-])cnc1COC(N)=O</smiles>

Ronidazole

(TRICHOREX $^{\circledR}$ )<smiles>Cn1c([N+](=O)[O-])cnc1N1CCN(S(C)(=O)=O)C1=O</smiles>

Satranidazole (SATROGYL $^{\circledR}$ )

Fig. (4).Most widely used 5-nitroimidazoles

The 5-nitroimidazole family, which has been the subject of decades of study, offers numerous pharmacological properties that make the compounds presented in the following sections suitable for a wide range of uses.

\section{A.1. Antiparasitic properties}

The main target parasites of nitroimidazole compounds are Entamoba histolytica, Giardia intestinalis, Balantidium coli and Trichomonas vaginalis[14].Trichomonas vaginalis, a flagellate protozoan, is responsible for $30 \%$ of non-gonococcal urethritis and for $50 \%$ of vaginitis with leukorrhea. The first patent for compounds having an anti-trichomonas activity was filed by the researchers of Rhône-Poulenc [15] in 1957, and the first synthesis of nitroimidazoles resulting from the study of biological activities appeared in 1966[16].These authors 
found that 4(5)-nitroimidazole (Fig.5)possessed an anti-trichomonas activity close to that of 2-nitroimidazole, but that its toxicity was approximately 10 times weaker.<smiles></smiles>

Fig. (5).4(5)-Nitroimidazole

This led to further studies on the 5-nitroimidazole moiety. Indeed, in 1970, Pfizer Inc.[17] demonstrated on the mouse that an electron-withdrawing group like sulfoneat the 1-position strengthened the anti-trichomonas activity in 5-nitroimidazole seriesas reported in tinidazole (Fig.4).

Also, Hoffer and Grunberg[18] substituted the 5-nitroimidazole moiety at the 1-position with alkyl chains possessing three carbonsas reported in ornidazole (Fig. 4). The resulting compounds showed good levels of activity against Trichomonas vaginalis, Trichomonas foetus and Entamoba histolytica.

The study on the structure-activity relationship realized by McCowen[19] showed that the presence of an ethylene double bond at the 2-position of the 5-nitromidazole moiety was essential to antiparasitic activity, in particular on Trypanosoma sp., Entamoba histolytica and Trichomonas vaginalisFig. (6).<smiles>[R]C=Cn1c([R7])cnc1[N+](=O)[O-]</smiles>

Fig. (6).Ethylene bond at the 2-position

While 5-nitroimidazole moieties have not been proved to have mutagenic activity on the human[20], certain studies revealed their mutagenic activity on prokaryotic cells[21-24].In a study concerning the influence of substituents on the activity and the mutagenicity of 5-nitroimidazoles, Walsh et al. demonstrated in 1987 that it was possible to considerably decrease the mutagenicity of these compounds, while conserving a comparable anti-trichomonas activity for ronidazole or metronidazole, the reference molecules, by incorporating substituents at the 4-position, like 2-(1,2-dimethyl-5-nitro-1H-imidazol-4-yl)ethanol (Fig. 7). Indeed, this compound possessed an anti-trichomonas activity $\left(\mathrm{IC}_{50}=10.8 \mu \mathrm{M}\right)$ close to those of ronidazole and metronidazole $\left(\mathrm{IC}_{50}=2.33 \mu \mathrm{M}\right)$, while showing only $4 \%$ of the mutagenicity of metronidazole and $0.28 \%$ of the mutagenicity of ronidazole.<smiles>Cc1nc(CCO)c([N+](=O)[O-])n1C</smiles>

Fig. (7).2-(1,2-Dimethyl-5-nitro-1H-imidazol-4-yl)ethanol

Focusing our attention on 5-nitroimidazoles and their reactivity towards $\mathrm{S}_{\mathrm{RN}} 1$, our group was able to synthesize the pyrrolidine derivative RP 57967, which has proved to be particularly active on Trichomonas vaginalis and Entamoba histolytica[25-27].The 1-methyl-3-[(1-methyl-5-nitro-1H-imidazol-2yl)methylene]pyrrolidin-2-one RP 57967 is very active on anaerobic bacteria, more active than metronidazole and dimetridazole. This molecule was prepared by $\mathrm{S}_{\mathrm{RN}} 1$ reaction of 2-chloromethyl-1-methyl-5-nitro-1Himidazole with 1-methyl-3-nitropyrrolidin-2-one lithium salt, followed by elimination of nitrous acid (Scheme 1). 
<smiles>Cn1c([N+](=O)[O-])cnc1CCl</smiles><smiles>C[C+](O)C1CCN(C)C1=O</smiles><smiles>CN1CC/C(=C\c2ncc([N+](=O)[O-])n2C)C1=O</smiles>

Scheme 1. Synthesis of RP 57967 compound

Extending this research focus, the study of 2-cycloheptylidenemethyl-1-methyl-5-nitro- $1 \mathrm{H}$-imidazole (Fig. 8) showed a better activity on anaerobic bacteria than metronidazole with an $\mathrm{IC}_{50}$ of $0.24 \mathrm{mg} / \mathrm{kg}$ on Clostridium perfringens as compared to $0.48 \mathrm{mg} / \mathrm{kg}$ for metronidazole[28].<smiles>Cn1c([N+](=O)[O-])cnc1C=C1CCCCCC1</smiles>

Fig. (8). 2-(Cycloheptylidenemethyl)-1-methyl-5-nitro-1H-imidazole

The same study also showed an amœbicidal activity and anti-trichomonas activity of (E)-2(bicyclo[2.2.1] heptan-2-ylidenemethyl)-1-methyl-5-nitro- $1 \mathrm{H}$-imidazole (Fig. 9)that was higher than that of metronidazole. Indeed, this product was 4 times as active on Trichomonas vaginalis $\left(\mathrm{IC}_{50}=0.5 \mu \mathrm{g} / \mathrm{mL}\right.$ ) as metronidazole $\left(\mathrm{IC}_{50}=2 \mu \mathrm{g} / \mathrm{mL}\right.$ ), and as active on Trichomonas foetus as metronidazole (the $\mathrm{IC}_{50}$ for both molecules being $3 \mu \mathrm{g} / \mathrm{mL}$ ).<smiles>Cn1c([N+](=O)[O-])cnc1C=C1CC2CCC1C2</smiles>

Fig. (9). (E)-2-(Bicyclo[2.2.1]heptan-2-ylidenemethyl)-1-methyl-5-nitro-1 $H$-imidazole

The 1992 studies of mutagenicity on 48 compounds via Ames tests and SOS chromotests showed strong mutagenicity for the tested products, in particular the RP 57967 molecule with an 1-methyl-2-pyrrolydinone-3ylidenemethyl group at the 2-position, which considerably increased the mutagenicity of the molecule compared to metronidazole[29].

In 2006, our team showed that there was good activity on Giardia intestinalis and metronidazole-resistantTrichomonas vaginalis strains by (E)-ethyl 2-methyl-3-\{4-[2-(1-methyl-5-nitro- $1 H$-imidazol-2-yl)vinyl]phenyl $\}$ 2-nitropropanoate (Fig. 10) [30].This product, resulting from an $L D-S_{\mathrm{RN}} 1$ study (Long Distance $-\mathrm{S}_{\mathrm{RN}} 1$ ), presented an $\mathrm{IC}_{50}$ of $1 \mu \mathrm{M}$ compared to $50 \mu \mathrm{M}$ for metronidazole.<smiles>CCOC(=O)C(C)(N)Cc1ccc(/C=C/c2ncc([N+](=O)[O-])n2C)cc1</smiles>

Fig. (10). (E)-Ethyl 2-methyl-3-\{4-[2-(1-methyl-5-nitro-1H-imidazol-2-yl)vinyl]phenyl\}-2-nitropropanoate

This study also showed an anti-trichomonas activity for 5 other products whose $\mathrm{IC}_{50}$ ranged from 25 to $50 \mu \mathrm{M}$ (Fig. 11). 

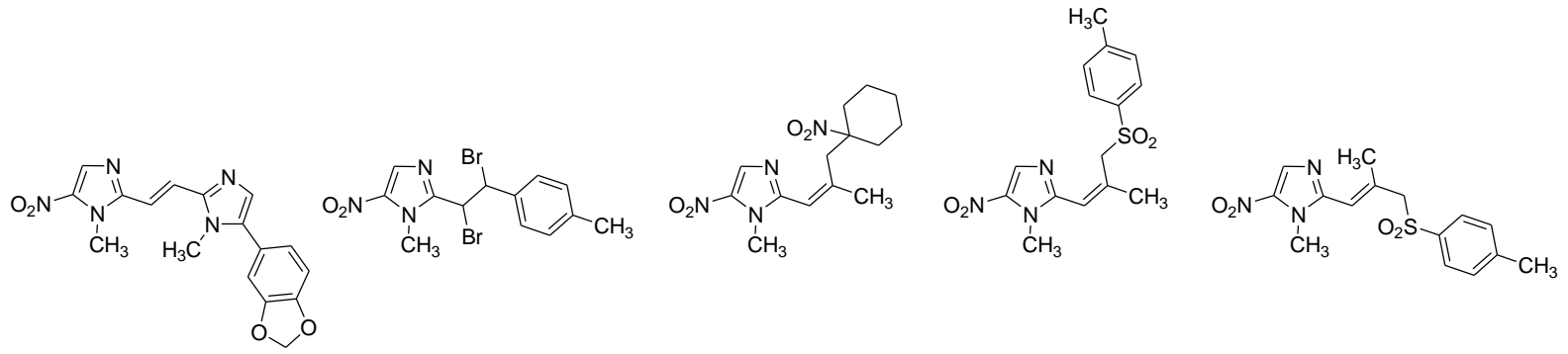

Fig. (11). $\mathrm{IC}_{50}$ ranged from 25 to $50 \mu \mathrm{M}$ in 5-nitroimidazole series

More recently, our team tested the anti-trichomonas activity (TV87 strain), the toxicity on a THP1 human cell strain and the mutagenicity (assay of mutagenicity on Salmonella typhimurium) of 24 products substituted by arylsulfonylmethyl groups in 4-position (Fig. 12).

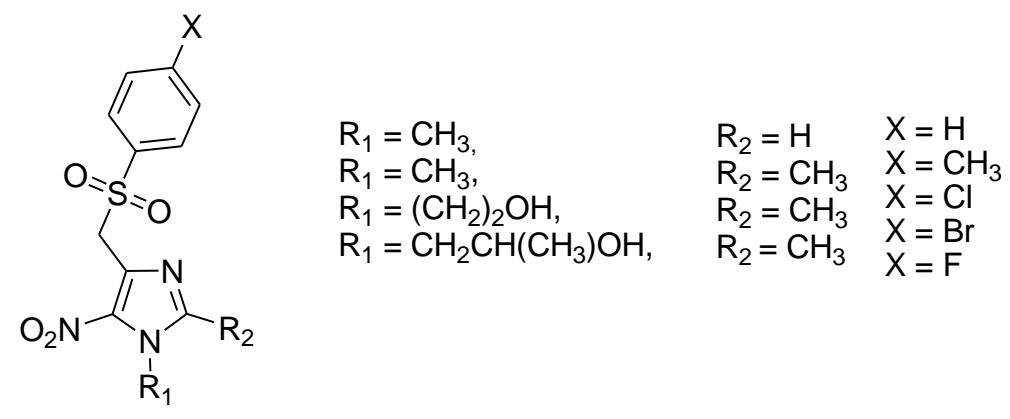

Fig. (12).24 products substituted by arylsulfonylmethyl groups in 4-position

This study showed that the 24 tested molecules presented an anti-trichomonas activity with $\mathrm{IC}_{50}$ ranging from $0.044 \mu \mathrm{M}\left(\mathrm{R}_{1}=\left(\mathrm{CH}_{2}\right)_{2} \mathrm{OH} \mathrm{R} \mathrm{R}_{2}=\mathrm{CH}_{3} \mathrm{X}=\mathrm{Cl}\right)$ to $2.746 \mu \mathrm{M}$ (metronidazole). In this series of molecules, 21 possessed a higher anti-trichomonas activity than metronidazole, and two possessed a similar activity. Fifteen molecules showed no toxicity on THP1 human cells, and the mutagenicity assay on Salmonella showed that the mutagenicity of these products decreased when they were concomitantly substituted by an arylsulfonylmethyl group at the 4-position and by a methyl group at the 2-position. The molecule which proved the most interesting was 2-\{4-[(4-chlorophenylsulfonyl)methyl]-2-methyl-5-nitro-1 $H$-imidazol-1-yl $\}$ ethanol $\left(\mathrm{R}_{1}=\left(\mathrm{CH}_{2}\right)_{2} \mathrm{OH} \mathrm{R}_{2}=\right.$ $\mathrm{CH}_{3} \mathrm{X}=\mathrm{Cl}$ ), with the best $\mathrm{IC}_{50}$, and a specificity index (ratio between the $\mathrm{IC}_{50}$ of the human cells and the $\mathrm{IC}_{50}$ of the parasites) of $13136[31]$.

In addition to the anti-trichomonas activity widely exploited within our laboratory, 5-nitroimidazole moieties present antiparasitic activities on other species which are the object of numerous studies. For example, Dunn et al. recently studied metronidazole-resistant strains of Blastocystissp., a unicellular protozoan causing intestinal disorders such as diarrhea, nausea, vomiting, constipation, intestinal pains, ranging from moderate to severe[32].These studies examined the mechanism of action as well as the resistance mechanisms of these strains in relation to existing treatments.

Finally, 1-methyl-2-\{[4-methylthio)phenoxy]methyl $\}-5$-nitro- $1 H$-imidazole, more commonly known under the name of fexinidazole (Fig. 13), was recently the object of numerous studies on Trypanosoma bruceigambiense and Trypanosoma brucei rhodesiense[33], leading to phase I studies in 2009 which will soon culminate in phase II/III studies.<smiles>CSc1ccc(OCc2ncc([N+](=O)[O-])n2C)cc1</smiles>

Fig. (13).Fexinidazole 
As well as their antiparasitic activity, 5-nitroimidazoles moieties present various biological properties making them useful in a variety of fields.

\section{A.2. Antibacterial properties}

5-Nitroimidazole moieties possess original antibacterial activity against anaerobic bacteria[34].They have bactericidal activity against anaerobic Gram-negative bacilli (Bacteroides, Fusobacterium), anaerobic nonsporulating Gram-positive bacilli such as Clostridium difficile, responsible for pseudomembranous colitis and for nosocomial diarrheas in immunocompromised patients or patients under postoperative antibiotic treatment, and against Gardnerella vaginalis. The sensitivity of the anaerobic Gram-negative cocci (Veillonella) and Grampositive cocci (Peptococcus, Peptostreptococcus) is unpredictable, and anaerobic non-sporulating Gram-positive bacilli are naturally resistant (Actinomyces, Propionibacterium). Used in association, nitroimidazoles are indicated to eradicate Helicobacter pylori involved in gastroduodenal ulcers.

\section{A.3. Radiosensitization properties}

During radiation therapy, radicals are created from oxygen. Many tumor cells are hypoxic and therefore have reduced sensitivity to radiation. For the treatment by radiotherapy of certain brain tumors in particular, it is useful to decrease hypoxic resistance. 5-Nitroimidazoles simulate oxygen, according to their electron affinity (oxygen effect)[35, 36], allowing normally resistant cells to be recruited to radiation.

\section{A.4. Limitations to use: Resistance to treatment}

Little is known about the mechanism of resistance to this type of compound. However, since the activity of 5-nitroimidazoles very probably depends on their reduction by enzymes acting as nitroreductases, such as pyruvate ferredoxin oxidoreductase[35, 36], a decrease in the activity of these enzymes may well explain resistance to these compounds[39].

Thus, Leitsch et al. who propose thioredoxin reductase as the principal means of activation of metronidazole, suggest that resistance to these compounds is linked to the activity of this enzyme[40, 41].

Rasoloson et al. show that the malic enzyme, present in hydrogenosome, is involved in the reduction of metronidazole and thus in the resistance of the strains concerned[42].

Finally, Pal et al. reveal alternative mechanisms of resistance, by means of other nitroreductase enzymes and the production by the treated parasites of nim genes similar to those present in anaerobic bacteria strains such as 5 nitroimidazole-resistant Bacteroides fragilis[43].

Some studies also suggest the mechanism of the efflux pump by proteins of the TolC family in bacteria like Helicobacter pylori[44].

Given that these molecules have been on the market for a long time, with the emergence of resistance to treatment leading to dose intensification and thus adverse drug reactions, and in view of the inherent mutagenicity of this compound family, we directed our research towards the synthesis of 5-nitroimidazole derivatives with the aim of avoiding these adverse drug reactions and decreasing mutagenicity, while at the same time contributing to a better understanding of their mechanism of action.

\section{Vicarious Nucleophilic Substitution of hydrogen in 5-nitro- imidazole series.}

While numerous examples of the VNS reaction are described from benzene and naphthalene derivatives and the nitrogenous analogues (pyridine, quinoline, acridine, and 1,2,4-triazine)[45-47],Makosza showed that 
this reaction was also possible with 5-membered nitrated monoheteroaromatic systems such as thiophene, furan or pyrrole[48].

Makosza also showed that the imidazole nucleus was sensitive to the nucleophilic movement of hydrogen according to the VNS reaction scheme, provided that it contains a nitro group as substituent[49]. As in strongly basic medium, nitro- $1 H$-imidazoles are converted in corresponding inactive form for nucleophilic additions, successful realization of a VNS reaction requires imidazole derivatives substituted at the 1-position.

1-Methyl-4-nitro-1H-imidazole reacts with chloromethylphenylsulfone in the presence of potassium hydroxide in the DMSO, leading to one single product: 1-methyl-4-nitro-5-phenylsulfonylmethyl- $1 H$-imidazole. Only position 5 is then activated by the nitro group (Scheme 2 ).

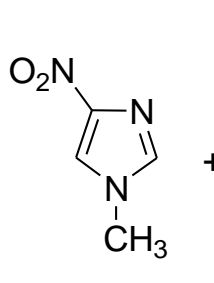<smiles>O=S(=O)(CCl)c1ccccc1</smiles>
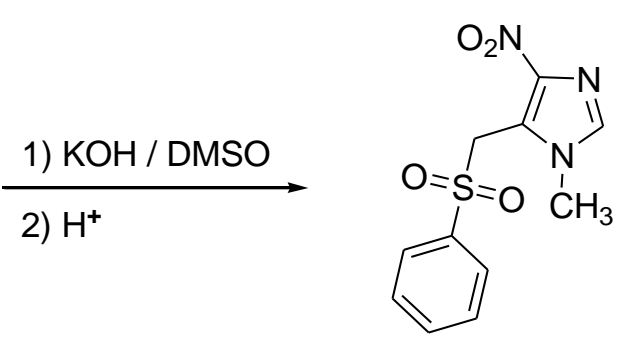

$83 \%$

Scheme 2.VNS reactivity between 1-methyl-4-nitro-1 $H$-imidazole and chloromethylphenylsulfone.

When the nitro group occupies the 5-position, as in the case of 1-methyl-5-nitro-1H-imidazole, two atoms of carbon are then likely to undergo a nucleophilic attack (carbons C-2 and C-4), potentially leading to either of two products of the VNS reaction. Makosza described the formation of both possible isomers during the VNS reaction between chloromethylphenylsulfone and 1-methyl-5-nitro- $1 \mathrm{H}$-imidazole, the isomer at the 4-position being always the major product (4-position /2-position = 4.8) (Scheme3)[49].<smiles>Cn1cncc1[N+](=O)[O-]</smiles>

Scheme 3.VNS reactivity between 1-methyl-5-nitro- $1 H$-imidazole and chloromethylphenylsulfone.

Finally, Makosza showed that this VNS reaction did not apply to imidazole derivatives without any electronwithdrawing group. Thus, neither 1 -methyl- $1 H$-imidazole nor 1,2-dimethyl-1H-imidazole react through a VNS reaction with chloromethylphenylsulfone, although there are some examples of reactions between halogenated derivatives of imidazoles not carrying an additional withdrawing group and nucleophilic agentsvia an $\mathrm{S}_{\mathrm{N}} \mathrm{Ar}$ mechanism[50].

Having presented the synthesis of five different chloromethylsulfones, we studied their reactivity via VNS reactions with the following 5-nitroimidazoles (Fig. 14):

- 1-methyl-5-nitro-1H-imidazole 1

- 1,2-dimethyl-5-nitro-1H-imidazole or dimetridazole 2 
- 2-(2-methyl-5-nitro-1H-imidazol-1-yl)ethanol or metronidazole 3

- $\quad$ 1-(2-methyl-5-nitro-1H-imidazol-1-yl)propan-2-ol or secnidazole 4<smiles>Cn1cncc1[N+](=O)[O-]</smiles>

1<smiles>Cc1ncc([N+](=O)[O-])n1C</smiles>

2<smiles>Cc1ncc([N+](=O)[O-])n1CCO</smiles>

3<smiles>Cc1ncc([N+](=O)[O-])n1CC(C)O</smiles>

Fig. (14).Starting materials in 5-nitroimidazole series.

\section{II.1. Synthesis of sulfonyl derivatives}

To synthesize the precursory chloromethylarylsulfones from VNS reactions, we based our approach on the work of Makosza. From the commercial sodium arylsulfinates, chloromethylarylsulfones 5-7 were obtained by addition of 15 equiv. of bromochloromethane in the DMSO at $58{ }^{\circ} \mathrm{C}$ for $6 \mathrm{~h}$ [51], with respective yields of $63 \%, 53 \%$ and $47 \%$ (Scheme 4)[52].

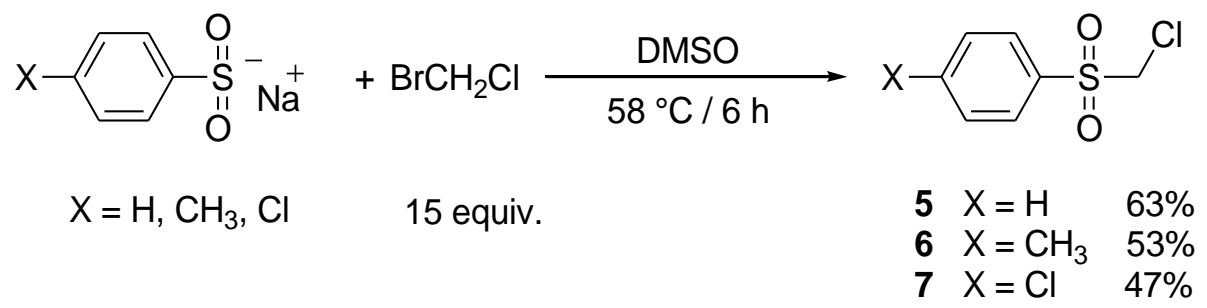

Scheme 4.Synthesis of chloromethylarylsulfones 5-7.

Sodium 4-bromobenzenesulfinate and sodium 4-fluorobenzenesulfinate not being commercially available, we were inspired by the method described by Antane [53] to synthesize 1-bromo-4chloromethylsulfonylbenzene $\mathbf{8}$ and 1-fluoro-4-chloromethylsulfonylbenzene $\mathbf{9}$. Thus, 4-bromobenzenesulfonyl chloride and 4-fluorobenzenesulfonyl chloride reacted with sodium sulfite and sodium hydrogenocarbonate in a refluxing water-DMSO mixture for $2 \mathrm{~h}$. After obtaining non-isolated sodium intermediate salts, bromochloromethane in excess with tetrabutylammonium bromide in catalytic quantity were added in situ, leading after $8 \mathrm{~h}$ at $75{ }^{\circ} \mathrm{C}$ to 1-bromo-4-(chloromethyl)sulfonylbenzene 8 [52] and 1-fluoro-4(chloromethyl)sulfonylbenzene 9 in respective yields of $67 \%$ and $65 \%$ (Scheme 5).

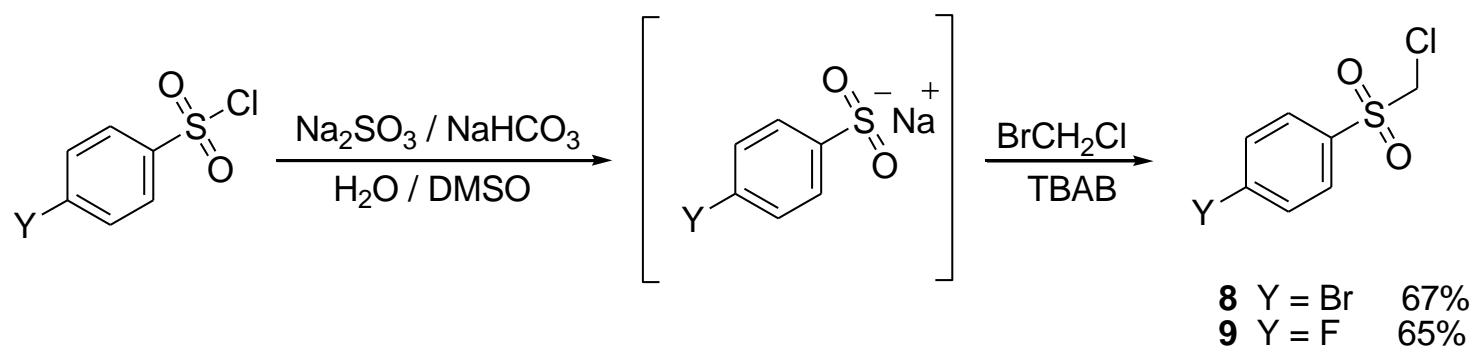

Scheme 5.Synthesis of chloromethylarylsulfones 8-9.

\section{II.2. Synthesis of 5-nitromidazole derivatives via VNS reaction}

Following in the footsteps of Makosza, we performed reactions of various imidazoles with chloromethylarylsulfones 5-9 in the presence of 5 equivalents of potassium hydroxide finely crushed in DMSO 
for $10 \mathrm{~min}[54]$.Thus, we synthesized 20 new compounds (10-29) with yields varying from 20 to $69 \%$ (Scheme 6).<smiles>[X]c1ccc(S(=O)(=O)CCl)cc1</smiles>

$$
\begin{array}{llll}
\mathbf{5} X=\mathrm{H} & \mathbf{1} & \mathrm{R}_{1}=\mathrm{CH}_{3} & \mathrm{R}_{2}=\mathrm{H} \\
\mathbf{6} X=\mathrm{CH}_{3} & \mathbf{2} & \mathrm{R}_{1}=\mathrm{CH}_{3} & \mathrm{R}_{2}=\mathrm{CH}_{3} \\
\mathbf{7} \mathrm{X}=\mathrm{Cl} & \mathbf{3} & \mathrm{R}_{1}=\left(\mathrm{CH}_{2}\right)_{2} \mathrm{OH} & \mathrm{R}_{2}=\mathrm{CH}_{3} \\
\mathbf{8} \mathrm{X}=\mathrm{Br} & \mathbf{4} & \mathrm{R}_{1}=\mathrm{CH}_{2} \mathrm{CH}\left(\mathrm{CH}_{3}\right) \mathrm{OH} & \mathrm{R}_{2}=\mathrm{CH}_{3} \\
\mathbf{9} X=\mathrm{F} & & &
\end{array}
$$

\begin{tabular}{|c|c|c|c|c|}
\hline \multicolumn{3}{|c|}{ Synthesized compounds via VNS } & \multirow{2}{*}{ Compound number } & \multirow{2}{*}{ Yield $(\%)^{\mathrm{b}}$} \\
\hline $\mathrm{X}$ & $\mathrm{R}_{1}$ & $\mathrm{R}_{2}$ & & \\
\hline $\mathrm{H}$ & $\mathrm{CH}_{3}$ & $\mathrm{H}$ & 10 & 55 \\
\hline $\mathrm{CH}_{3}$ & $\mathrm{CH}_{3}$ & $\mathrm{H}$ & 11 & 29 \\
\hline $\mathrm{Cl}$ & $\mathrm{CH}_{3}$ & $\mathrm{H}$ & 12 & 42 \\
\hline $\mathrm{Br}$ & $\mathrm{CH}_{3}$ & $\mathrm{H}$ & 13 & 57 \\
\hline $\mathrm{F}$ & $\mathrm{CH}_{3}$ & $\mathrm{H}$ & 14 & 54 \\
\hline $\mathrm{H}$ & $\mathrm{CH}_{3}$ & $\mathrm{CH}_{3}$ & 15 & 28 \\
\hline $\mathrm{CH}_{3}$ & $\mathrm{CH}_{3}$ & $\mathrm{CH}_{3}$ & 16 & 20 \\
\hline $\mathrm{Cl}$ & $\mathrm{CH}_{3}$ & $\mathrm{CH}_{3}$ & 17 & 49 \\
\hline $\mathrm{Br}$ & $\mathrm{CH}_{3}$ & $\mathrm{CH}_{3}$ & 18 & 53 \\
\hline $\mathrm{F}$ & $\mathrm{CH}_{3}$ & $\mathrm{CH}_{3}$ & 19 & 40 \\
\hline $\mathrm{H}$ & $\left(\mathrm{CH}_{2}\right)_{2} \mathrm{OH}$ & $\mathrm{CH}_{3}$ & 20 & 24 \\
\hline $\mathrm{CH}_{3}$ & $\left(\mathrm{CH}_{2}\right)_{2} \mathrm{OH}$ & $\mathrm{CH}_{3}$ & 21 & 24 \\
\hline
\end{tabular}

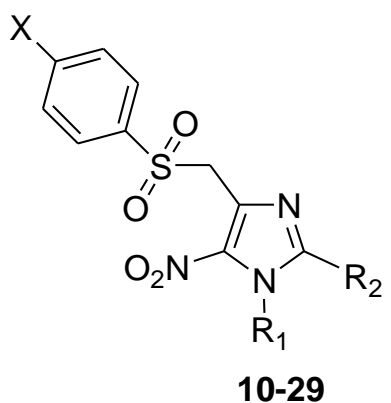

Scheme 6.Synthesis of 4-arylsulfonylmethyl derivatives via VNS reaction.

The results of these reactions are summarized in Table $\mathbf{1 .}$

Table 1.Preparation of 1,2-Dialkyl-4-arylsulfonylmethyl-5-nitro-1 $H$-imidazoles and 4-Arylsulfonylmethyl-1-methyl-5-nitro-1H-imidazoles ${ }^{\mathrm{a}}$. 


\begin{tabular}{ccc|cc}
\hline $\mathrm{Cl}$ & $\left(\mathrm{CH}_{2}\right)_{2} \mathrm{OH}$ & $\mathrm{CH}_{3}$ & $\mathbf{2 2}$ & 41 \\
$\mathrm{Br}$ & $\left(\mathrm{CH}_{2}\right)_{2} \mathrm{OH}$ & $\mathrm{CH}_{3}$ & $\mathbf{2 3}$ & 51 \\
$\mathrm{~F}$ & $\left(\mathrm{CH}_{2}\right)_{2} \mathrm{OH}$ & $\mathrm{CH}_{3}$ & $\mathbf{2 4}$ & 20 \\
$\mathrm{H}$ & $\mathrm{CH}_{2} \mathrm{CH}\left(\mathrm{CH}_{3}\right) \mathrm{OH}$ & $\mathrm{CH}_{3}$ & $\mathbf{2 5}$ & 37 \\
$\mathrm{CH}_{3}$ & $\mathrm{CH}_{2} \mathrm{CH}\left(\mathrm{CH}_{3}\right) \mathrm{OH}$ & $\mathrm{CH}_{3}$ & $\mathbf{2 6}$ & 51 \\
$\mathrm{Cl}$ & $\mathrm{CH}_{2} \mathrm{CH}\left(\mathrm{CH}_{3}\right) \mathrm{OH}$ & $\mathrm{CH}_{3}$ & $\mathbf{2 7}$ & 69 \\
$\mathrm{Br}$ & $\mathrm{CH}_{2} \mathrm{CH}\left(\mathrm{CH}_{3}\right) \mathrm{OH}$ & $\mathrm{CH}_{3}$ & $\mathbf{2 8}$ & 17 \\
$\mathrm{~F}$ & $\mathrm{CH}_{2} \mathrm{CH}\left(\mathrm{CH}_{3}\right) \mathrm{OH}$ & $\mathrm{CH}_{3}$ & $\mathbf{2 9}$ & \\
\hline
\end{tabular}

${ }^{a}$ All reactions follow the same procedure: $\mathrm{KOH}$ (5 equiv.), 1,2-dialkyl-5-nitro- $1 H$-imidazole (1 equiv.) or 1methyl-5-nitro- $1 H$-imidazole ( 1 equiv.), chloromethylarylsulfone (1 equiv.), DMSO.

${ }^{\mathrm{b}}$ Yields are calculated compared with $\mathbf{1 , 2 , 3}$ or $\mathbf{4}$, on the isolated products by silicagel column chromatography and by recrystallization.

During the reaction between 1-methyl-5-nitro- $1 \mathrm{H}$-imidazole 1 and chloromethylsulfones 5-9, we expected to obtain a mixture of substituted compounds at the 2-position and at the 4-position, positions which in theory promote VNS reactions according to the results of Makosza[54].

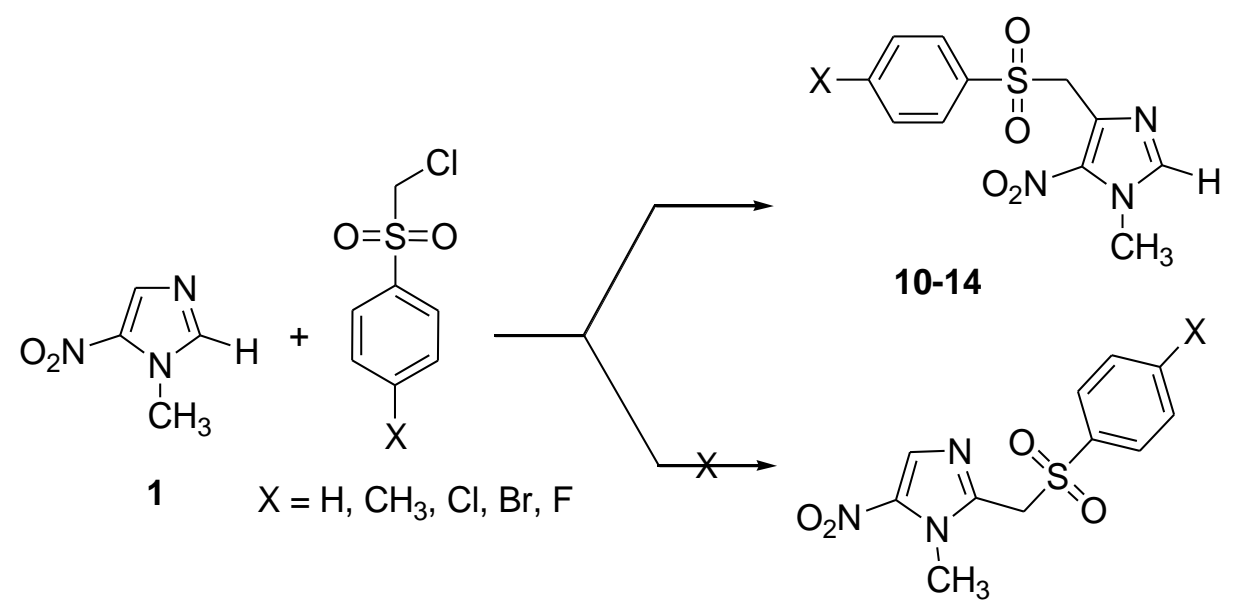

Scheme 7.Formation of 5-nitroimidazole derivatives in 4-position.

Here, however, only compounds 10-14 substituted at the 4-position were isolated (Scheme 7), as confirmed by X-ray analysis of 1-methyl-5-nitro-4-phenylsulfonylmethyl- $1 H$-imidazole 10(Fig.15). The other structures were assigned by analogy and spectral comparison. 


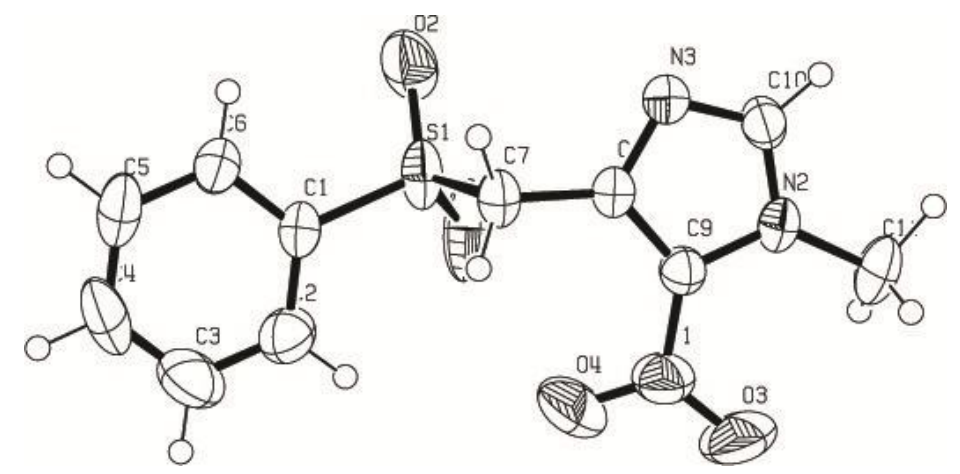

Fig. (15).ORTEP structure of 1-methyl-5-nitro-4-(phenylsulfonylmethyl)-1H-imidazole 10.

\section{II.3. Biological evaluation}

13 of the compounds tested showed a better activity than metronidazole on Trichomonas vaginalis, and 5 have an index of selectivity better than those of both reference products: products 10, 11, 15, 22 and 26 . The best result is obtained with compound 22, which has a remarkable index of selectivity of 13005 , compared to 531.95 for metronidazole. This compound possesses an antiparasitic activity 20.4 times greater than that of metronidazole and 4.35 times greater than that of dimetridazole[31].

The incorporation of an arylmethylsulfone substituent at the 4-position of 5-nitroimidazole seems to promote antiparasitic activity.

\section{Palladium-catalyzed cross-coupling in 5-nitroimidazole series.}

\section{III.A. Suzuki-Miyaura cross-coupling in 4-bromo-1,2-dimethyl-5-nitro- $1 H$-imidazole series}

We extended our research by focusing on how heating contributes to the Suzuki-Miyaura crosscoupling under microwave irradiation. The required starting material for the Suzuki-Miyaura cross-coupling reaction is 4-bromo-1,2-dimethyl-5-nitro- $1 H$-imidazole 31. Unfortunately, it is impossible to obtain this compound in good yields, directly from the "direct" non-halogenated precursor (dimetridazole or 1,2-dimethyl-5nitro- $1 \mathrm{H}$-imidazole). Sunjic et al.[55] noted that the reaction of direct bromination of 1-alkyl-2-methyl-5-nitro$1 \mathrm{H}$-imidazole is not possible because of the poor reactivity of the 4-position towards the electrophilic substitution reactions. We therefore decided to brominate the 2-methyl-4(5)-nitro- $1 H$-imidazole as proposed by Bhujanga Rao et al.[56] with the dibrome (1.1 equiv.) in DMF (Scheme 8).

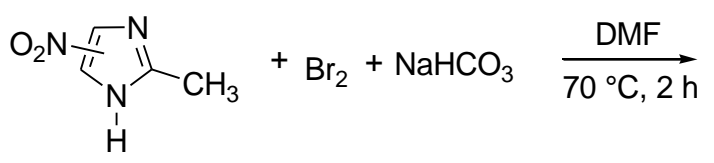<smiles>Cc1nc(Br)c([N+](=O)[O-])[nH]1</smiles><smiles>Cc1nc([N+](=O)[O-])c(Br)[nH]1</smiles>

Scheme 8. Synthesis of 4(5)-bromo-2-methyl-5(4)-nitroimidazole 30.

4(5)-Bromo-2-methyl-5(4)-nitro- $1 H$-imidazole was methylated by dimethylsulfate (DMS), following the procedure proposed by Sunjic et al.(Scheme 9)[53]. Furthermore, during the treatment by ammoniac solution, the product 33 was obtained in $24 \%$ yield. 
<smiles>CNc1nc(C)n(C)c1[N+](=O)[O-]</smiles>

Schema 9.Synthesis of required starting material 31 .

The first Suzuki-Miyaura cross-coupling assay was performed under the following experimental conditions: 10 mol \% of $\mathrm{Pd}\left(\mathrm{PPh}_{3}\right)_{4}$ (as catalyst), 5 equiv. of $\mathrm{Na}_{2} \mathrm{CO}_{3}$ (as base), 1.3 equiv. of arylboronic acid derivative and 1 equiv. of tetrabutylammonium bromide (TBAB) in water, under microwave irradiation [57].

Unfortunately, these experimental conditions were not generalizable to 4-bromo-1,2-dimethyl-5-nitro- $1 \mathrm{H}$ imidazole. Various experimental conditions of cross-coupling reactions were thus tested, to study their influence on reactivity. All the assays were conducted with 4-bromo-1,2-dimethyl-5-nitro- $1 H$-imidazole $\mathbf{3 1}$ and phenylboronic acid, in a multimode synthesis microwave oven (ETHOS Synth Lab Station) or by the classic heating method.

Six reaction parameters were tested (number of equiv. of arylboronic acid, nature of solvent, nature of base, catalyst species, phase transfer agent, heating method). As a result, the best microwave-assisted experimental conditions were defined, allowing the synthesis of 1,2-dimethyl-5-nitro-4-phenyl- $1 \mathrm{H}$-imidazole $\mathbf{3 4}$ in $93 \%$ yield in $1 \mathrm{~h}$. To prepare compound 34, 4-bromo-1,2-dimethyl-5-nitro- $1 \mathrm{H}$-imidazole 31 and 0.034 equiv. of $\mathrm{Pd}\left(\mathrm{PPh}_{3}\right)_{4}$ were dissolved in 1,2-dimethoxyethane (DME) and were mixed for $1 \mathrm{~h}$. A solution of phenylboronic acid in ethanol and 3 equiv. of $\mathrm{Na}_{2} \mathrm{CO}_{3}$ were added. Finally, the mixture was heated under microwave irradiation (150 W) (Scheme 10).

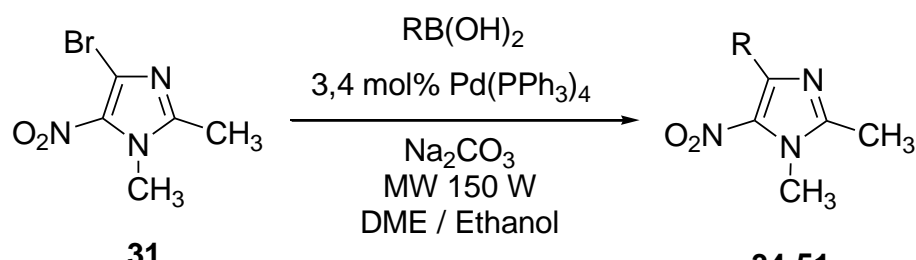

Scheme 10. Microwave-assisted palladium-catalyzed Suzuki-Miyaura cross-coupling reactions of compound 31 with different aryl, heteroaryl ou styrylboronic acids using $\mathrm{Pd}\left(\mathrm{PPh}_{3}\right)_{4}$.

To estimate the scope and limitations of this procedure, we performed cross-coupling reactions with 18 variously substituted boronic acid derivatives. The results show that this cross-coupling reaction is applicable to all the aryl, heteroaryl and styrylboronic acids used in our study(Table 2) [58].

Table 2.Products and Yields of Microwave-Assisted Palladium-Catalyzed Suzuki-Miyaura CrossCoupling Reactions of Compound 31 with Different Aryl, Heteroaryl orStyrylboronic acids using $\mathbf{P d}\left(\mathbf{P P h}_{3}\right)_{4}$.

\begin{tabular}{lllll}
\hline Entry & Boronic acid & $\begin{array}{c}\text { Compound } \\
\text { number }\end{array}$ & Yield $\%$ \\
\hline & & 34 & 1 & 33
\end{tabular}


2<smiles></smiles>

3<smiles>O[Hg](O)c1ccc(Cl)cc1</smiles><smiles>C#Cc1cccc([R9](O)(O)O)c1</smiles>

5<smiles>O=[N+]([O-])c1cccc(B(O)O)c1</smiles>

6<smiles>O[R9](O)c1cc(C(F)(F)F)cc(C(F)(F)F)c1</smiles><smiles>COc1ccc(O)cc1</smiles><smiles>COc1cc(O)cc(O)c1O</smiles>

8

9<smiles>OCc1ccc([18OH])cc1</smiles>

10<smiles>CCc1ccccc1O</smiles><smiles>Cc1nc(-c2ccc(F)cc2)c([N+](=O)[O-])n1C</smiles>

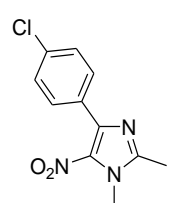<smiles></smiles>

37 68<smiles>CC1C(C)C2([N+](=O)[O-])C(c3cccc([N+](=O)[O-])c3)NC2N1C</smiles><smiles>Cc1c[nH]c([N+](=O)[O-])n1</smiles>

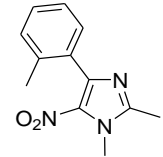


11<smiles>OB(O)c1ccc(-c2ccccc2)cc1</smiles>

12<smiles>OB(O)c1ccc2ccccc2c1</smiles><smiles>OB(O)c1cccc2ccccc12</smiles>

14<smiles>OBc1ccco1</smiles>

15<smiles>Cc1ccc([BH2-]O)s1</smiles>

16<smiles>OB(O)C=Cc1ccccc1</smiles>

17<smiles>OB(O)/C=C/c1ccc(C(F)(F)F)cc1</smiles><smiles>Cc1ccc(/C=C/B(O)O)cc1</smiles><smiles>Cc1nc(-c2ccc(-c3ccccc3)cc2)c([N+](=O)[O-])n1C</smiles><smiles>Cc1nc(-c2ccc3ccccc3c2)c([N+](=O)[O-])n1C</smiles><smiles>Cc1nc(C=O)c([N+](=O)[O-])n1C</smiles><smiles>Cc1ccc(-c2nc(C)n(C)c2[N+](=O)[O-])s1</smiles><smiles>Cc1nc(/C=C/c2ccccc2)c([N+](=O)[O-])n1C</smiles><smiles>Cc1nc(/C=C/c2ccc(C(F)(F)F)cc2)c([N+](=O)[O-])n1C</smiles>

Conditions: $\mathrm{Pd}\left(\mathrm{PPh}_{3}\right)_{4} 3.4$ mol\%, 4-bromo-1,2-dimethyl-5-nitro-1H-imidazole (1 equiv.), arylboronic acid (1.03 equiv.) or heteroarylboronic acid (1.03 equiv.) or (E)-styrylboronic acid (1.03 equiv.), $\mathrm{Na}_{2} \mathrm{CO}_{3}$ (3 equiv.), $\mathrm{DME} /$ Ethanol. An initial microwave irradiation of $150 \mathrm{~W}$ was used, being increased from ambient temperature to $75^{\circ} \mathrm{C}$ and then maintained for time $t$.

Under these experimental conditions we synthesized, by reaction with $(E)$-styrylboronic acid, $(E)$-4(trifluoromethyl)styrylboronic acid and (E)-4-methylstyrylboronic acid, compounds 49-51 in good yields (Table 2, entries 16-18). This method constitutes a valuable alternative to the Heck reaction. Indeed, to the best of our knowledge, there is only one description in the literature of the Heck reaction on 4-bromo-1,2-dimethyl-5-nitro- 
$1 \mathrm{H}$-imidazole31. Furthermore, the reaction is $100 \%$ stereoselective. X-ray structure analysis of a crystal of compounds 49 and 50 confirmed the presence of $E$-isomer alone (Fig.16).

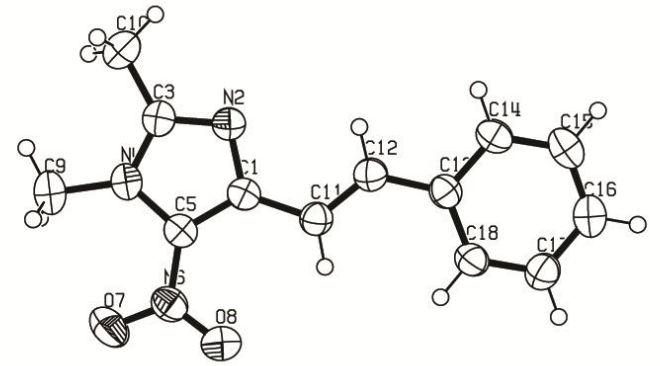

49

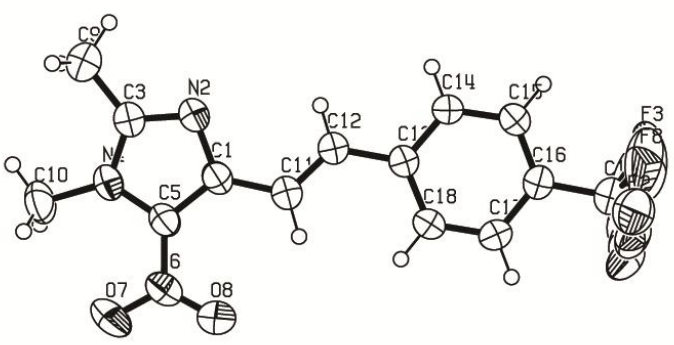

50

Fig.(16). ORTEP structures of (E)-1,2-dimethyl-5-nitro-4-styryl-1H-imidazole (49) and (E)-1,2-dimethyl-5nitro-4-[4-(trifluoromethyl)styryl]-1H-imidazole (50).

\section{III.B. Palladium-catalyzed $O$-arylation in 4-(4-fluoro-3-nitrophenyl)- 1,2-dimethyl-5-nitro-1H-imidazole series}

During the course of our research on the chemistry of new safer antiprotozoal [59] agents in 5nitroimidazole series[25, 27, 28, 30-32, 39, 52, 60-64], we observed what appeared to be palladium-catalyzed $O$ arylation of an aryl fluoride.

The development of mild conditions for the synthesis of diaryl ethers has attracted considerable attention, mainly due to their biological activity[64-71].Reactions used to generate aryl ethers appear in the literature, e.g. the $\mathrm{Cu}-$ promoted arylation of alcohol derivatives with phenylboronic acids known as Chan-Lam coupling[72-74],the $\mathrm{Cu}$-mediated Ullmann condensation[75-78] of phenols with aryl halides and the Buchwald's palladium-catalyzed C-O coupling[79-82] of phenols with aryl halides. However, to the best of our knowledge, no example of diaryl ether synthesis using arylboronic acid and aryl halides under the catalytic effects of palladium species has ever been described.

The required starting material was obtained by nitration using a mixture of $\mathrm{HNO}_{3} 60 \% / \mathrm{H}_{2} \mathrm{SO}_{4}$ of compound 35 (Scheme 11).

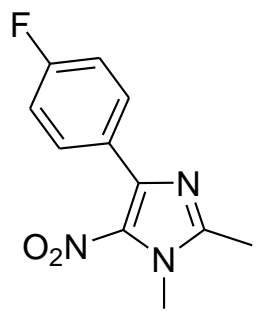

35

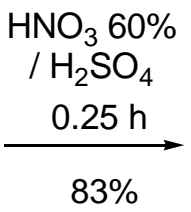<smiles>Cc1nc(-c2ccc(F)c([N+](=O)[O-])c2)c([N+](=O)[O-])n1C</smiles>

52

Scheme 11.Preparation of starting material 52.

Compound 52, reacted with 4-methoxyphenylboronic acid in classical Suzuki-Miyaura reaction conditions using $\mathrm{Pd}(\mathrm{OAc})_{2}$ /xantphos catalyst, $\mathrm{Cs}_{2} \mathrm{CO}_{3}$ under inert atmosphere in $\mathrm{DME}$ at $70{ }^{\circ} \mathrm{C}$ in the presence of tetrabutylammonium bromide (TBAB), gave unexpected methoxyphenoxy derivative $\mathbf{5 4}$ in $60 \%$ yield, and traces of nitrophenol derivative $\mathbf{6 0}$ instead of the expected C-C coupled derivative 53. Adding 10 equiv. of water to the same reaction medium afforded compound $\mathbf{5 4}$ in similar yields (51\% vs $60 \%$ without addition of water). 
Thus, the formation of compound $\mathbf{6 0}$ could result from an $S_{N} A r$ reaction between compound 35 and either carbonate or hydroxide anion as oxygen sources. Then, this reactivity was confirmed with other boronic acids, giving $O$-arylated compounds $\mathbf{5 5 - 5 9}$ in 30 to $79 \%$ yields (Scheme $\mathbf{1 2}$ ).<smiles>Cc1nc(-c2ccc(F)c([N+](=O)[O-])c2)c([N+](=O)[O-])n1C</smiles>

35

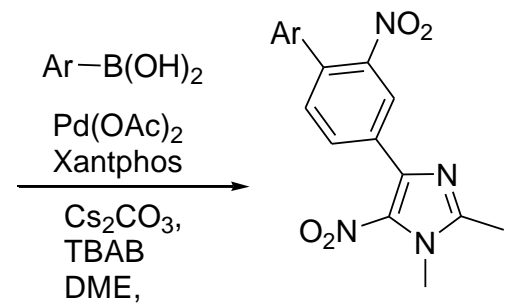

$530 \%$<smiles>Cc1nc(-c2ccc(OCBr)c([N+](=O)[O-])c2)c([N+](=O)[O-])n1C</smiles>

$54 \mathrm{Ar}=p-\mathrm{MeO}-\mathrm{C}_{6} \mathrm{H}_{4} 60 \%$

$55 \mathrm{Ar}=p-\mathrm{Me}^{-} \mathrm{C}_{6} \mathrm{H}_{4} \quad 53 \%$

$56 \mathrm{Ar}=p-\mathrm{Cl}-\mathrm{C}_{6} \mathrm{H}_{4} \quad 30 \%$

$57 \mathrm{Ar}=\mathrm{C}_{6} \mathrm{H}_{4} \quad 79 \%$

$58 \mathrm{Ar}=0-\mathrm{Me}-\mathrm{C}_{6} \mathrm{H}_{4} \quad 18 \%$

$59 \mathrm{Ar}=4$-pyridinyl $37 \%$<smiles>Cc1nc(-c2ccc(O)c([N+](=O)[O-])c2)c([N+](=O)[O-])n1C</smiles>

60 traces

Scheme 12. Reaction of $\mathbf{3 5}$ and boronic acids.

X-Ray spectroscopyof 54 and 55 (Fig.17) and HRMS spectrum of these four compounds confirmed the C-O bond formation.

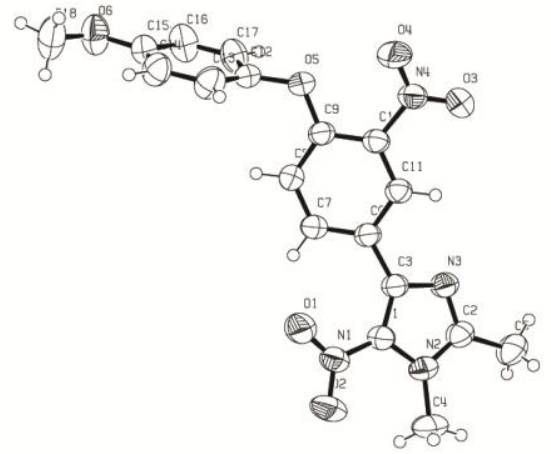

54

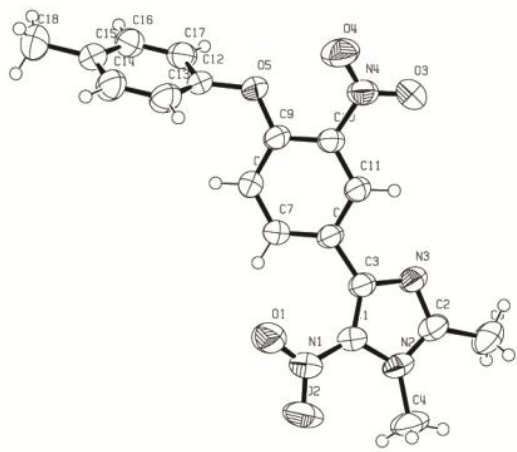

55

Fig.(17). Ortep drawings of 54 and 55.

Since palladium-catalyzed $O$-arylation had never been described with arylboronic acids and electron-deficient aryl fluorides, additional experiments were performed to further clarify the mechanism of the C-O bond formation. Palladium catalysis, boron species, oxidation conditions were investigated.

We hypothesized that a possible mechanism for the $O$-arylation could be via the intermediate $\mathbf{6 1}$ after palladium oxidative addition and cross-coupling with arylboronic acids, even though, to the best of our knowledge, no such palladium addition had ever been described.

In order to propose a mechanism, supposing the in situ formation of compound 61, we realized a special assay using the same reaction conditions and 1 equiv. of compound $\mathbf{6 0}$. Thus, with $p$-chlorophenylboronic acid, the desired product $\mathbf{5 6}$ was formed in $30 \%$ yield. In order to confirm the proposed mechanism, compound $\mathbf{6 1}$ was synthesized by reaction with aryl fluoride derivative 35 and nitrophenol derivative $\mathbf{6 0}$ under base-mediated conditions.Then, compound $\mathbf{6 1}$ was tested with 4-methoxyphenylboronic acid under the above experimental conditions. After $48 \mathrm{~h}$, a conversion of 61 in $O$-arylated compound 54 (39\%), nitrophenol 60 (60\%) and $C$ arylated compound $\mathbf{5 3}$ (traces) was observed, suggesting the mechanism depicted in scheme $\mathbf{1 3 .}$ 


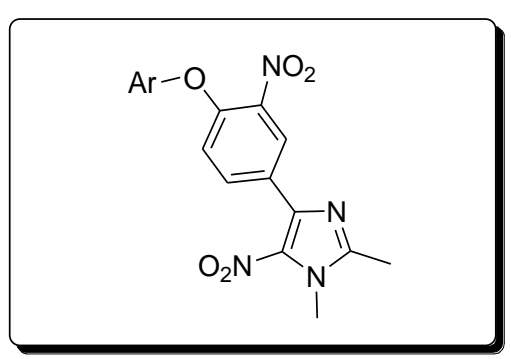

Reductive elimination<smiles>C/C=C/O[Z7]=[Te]</smiles>

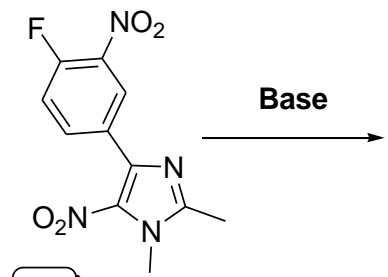

35
(NO)

60

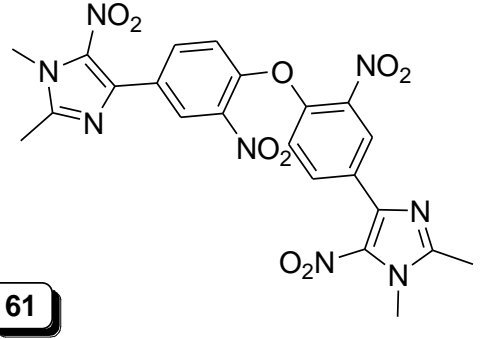
addition<smiles>Cc1nc(-c2ccc(OP(C)C)c([N+](=O)[O-])c2)c([N+](=O)[O-])n1C</smiles>

$\mathrm{Pd}^{0}$<smiles>C1CCCCC1</smiles>
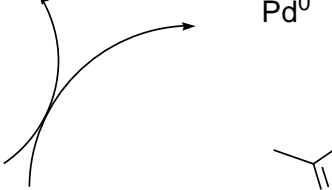

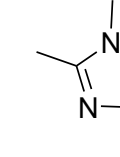

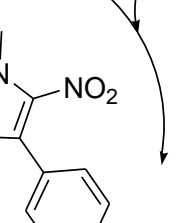
$\mathrm{O}_{2}$

Scheme 13.Proposed mechanism of C-O bond formation.

This work was the first example of a palladium-catalyzed C-O bond formed from a reaction between an activated phenylfluoride derivative and aryl or heteroaryl boronic acids[83].

\section{III.C. Sonogashira cross-coupling reactions in 4-bromo-1,2-dimethyl-5- nitro-1H-imidazole series}

In continuation of our research program centered on the design and synthesis of novel molecules, we focused our work on the synthesis and the evaluation of some heterocyclic compounds displaying diverse biological activities[84-88].We report in this section the preparation of 5-nitroimidazoles bearing alkynyl derivatives at the 4-position to widen anti-infectious pharmacomodulation in 5-nitroimidazole series. Furthermore, the 4-alkynylimidazole scaffold can be found in glutamate receptor antagonist molecules used for the treatment of central nervous system diseases (Alzheimer, Parkinson, Huntington's chorea, ...)[89-91].4Alkynyl-5-nitroimidazoles are also useful as substrates in organic synthesis. As Michael acceptors, they may react via the attack of nucleophilic species[92-94],particularly of azide [95], and could not only constitute good candidate substrates for Huisgen cycloaddition, but also provide molecules able to react through electron transfer reactions like $\mathrm{S}_{\mathrm{RN}} 1$ [96] and TDAE-assisted methodology [97]. 
Although the Sonogashira reaction has proved to be extremely versatile, being used extensively in natural products[98-105] and heterocyclic synthesis[106, 107], only a few examples of Sonogashira cross-coupling reactions in 4-bromoimidazole series are reported in the literature[108-111].Moreover, to the best of our knowledge, only one example of a Sonogashira reaction performed on a nitrated imidazole ring was described[89].Unfortunately, under these conditions it was not possible to perform the Sonogashira crosscoupling between 4-bromo-1,2-dimethyl-5-nitro-1H-imidazole (31) and propargylic alcohol, so a more general method providing easy access to 4-alkynyl-5-nitroimidazoles was investigated.

The required starting material for the Sonogashira cross-coupling reaction is the 4-bromo-1,2-dimethyl-5-nitro$1 \mathrm{H}$-imidazole 31 which was prepared in $22 \%$ overall yield (cf. III.A. section).

Basing ourselves on the reportedSonogashira reactions[89, 108-117],we tested different cross-coupling reaction conditions, focusing on 5 parameters: catalyst, co-catalyst, base, solvent, heating method.

As a result, optimized microwave-assisted experimental conditions were established and led to the synthesis of 3-(1,2-dimethyl-5-nitro-1H-imidazol-4-yl)prop-2-yn-1-ol 62 in 93\% yield in $1 \mathrm{~h}[118]$.The best experimental conditions were found to be $\mathrm{Pd}\left(\mathrm{PPh}_{3}\right)_{4}$ (0.05 equiv.); $\mathrm{CuI}(0.1$ equiv.); propargylic alcohol (2.0 equiv.) and $\mathrm{Bu}_{4} \mathrm{NOAc}\left(1.1\right.$ equiv.) in MeCN under microwave irradiation $\left(60{ }^{\circ} \mathrm{C}\right)$ for $1 \mathrm{~h}$. $\mathrm{PdCl}_{2}\left(\mathrm{PPh}_{3}\right)_{2}$ as palladium source and DMF as solvent gave similar results. Using $\mathrm{Et}_{3} \mathrm{~N}$ as base led to cross-coupling in only a moderate yield (40\%). Currently, the reasons for the beneficial effect of $\mathrm{Bu}_{4} \mathrm{NOAc}$ in these reactions are not clear. Undoubtedly, $\mathrm{Bu}_{4} \mathrm{NOAc}$ acts as a mild base to deprotonate the most acidic hydrogen in the alkyne, but according to Urgaonkar[117] the acetate anion in combination with a bulky cation could also play a crucial role by providing a naked more reactive acetate anion or by stabilizing the oxidative addition adduct $\mathrm{ArPd}^{(\mathrm{II})} \mathrm{X}$.

To evaluate the scope and the limitations of this procedure, we performed coupling reactions with 24 variously substituted terminal alkynes (Table 3).

Table 3. Microwave-Mediated Sonogashira Coupling Reactions of Imidazole 31 with Alkyl- or PhenylAcetylene.
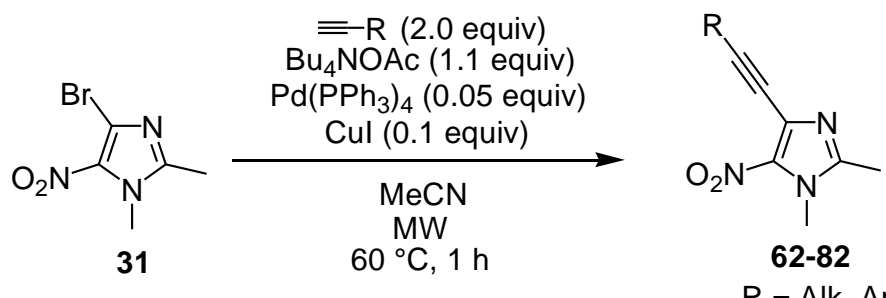

\begin{tabular}{|c|c|c|c|}
\hline Entry & Alkyne & Product & $\begin{array}{l}\text { Compound } \\
\text { Number }\end{array}$ \\
\hline & & $\mathrm{OH}$ & \\
\hline 1 & & & 62 \\
\hline
\end{tabular}


2

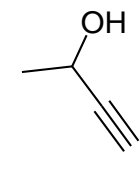

$\mathrm{HO}$

3

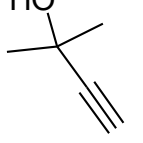<smiles>C#CC(O)C(C)C</smiles>

5<smiles>C#CC(C)(O)c1ccccc1</smiles>

6<smiles>C#CC(O)(c1ccccc1)c1ccccc1</smiles>

7

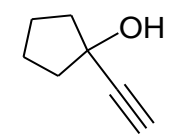

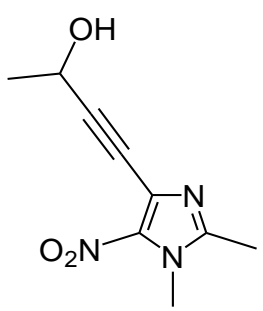

63

64

72

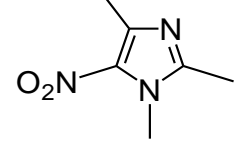

65

52

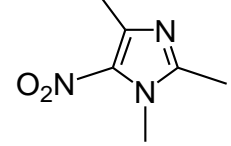

66

80

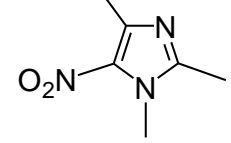<smiles>Cc1nc(C#CC2(O)CCCC2)c([N+](=O)[O-])n1C</smiles>

67

84

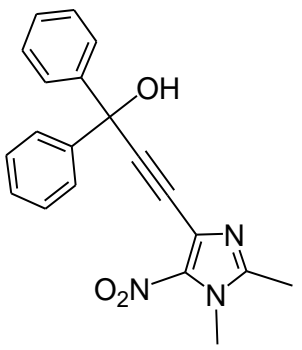

68

98 
8<smiles>C#CC1(O)CCCCC1</smiles>

9

10
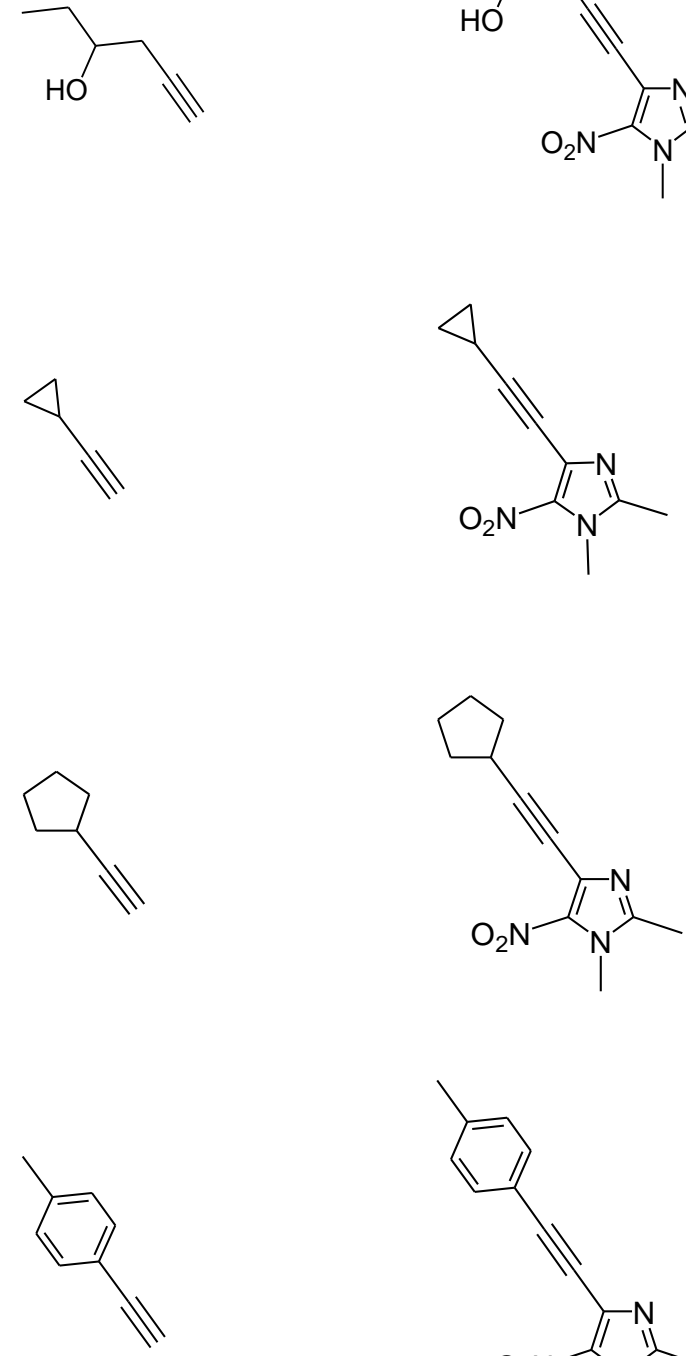

12

13

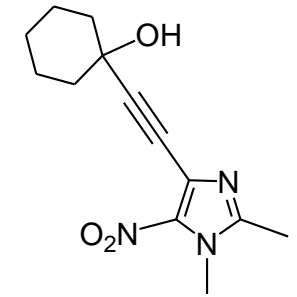

69

98

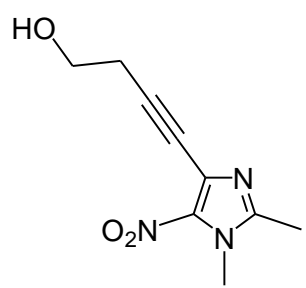

70

87

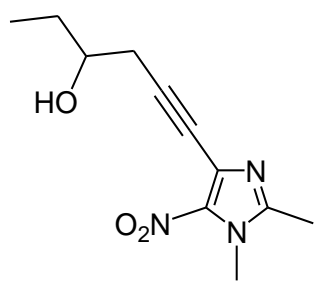

71

79

72

54

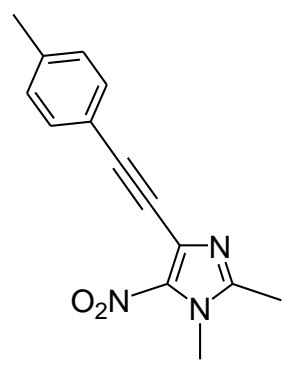

73

72

74

98 
14<smiles>C#Cc1ccccc1C</smiles>

15

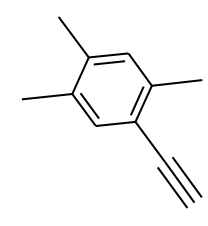

16

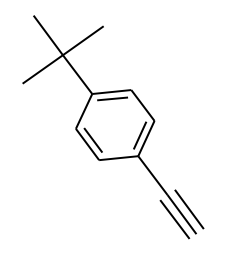

17<smiles>C#Cc1cccc(OC)c1</smiles>

18

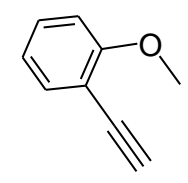

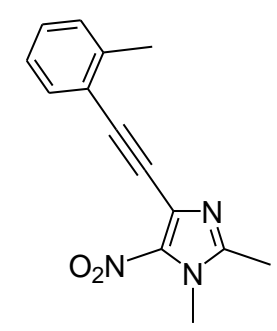

75

78

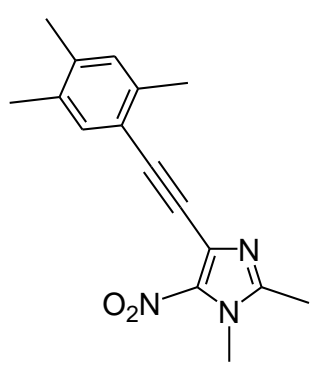

76

93

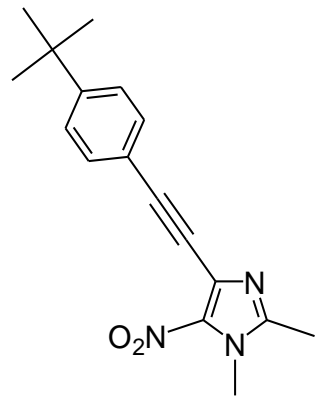

77

80

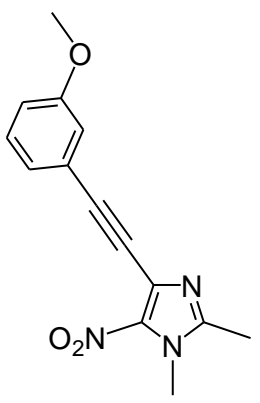

78

94

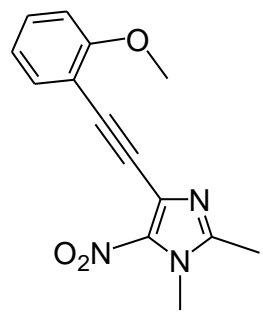


19

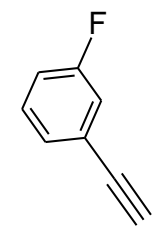

20

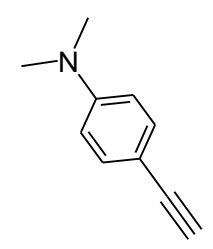

21

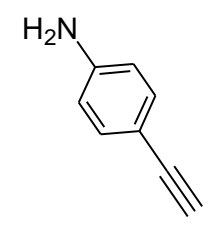

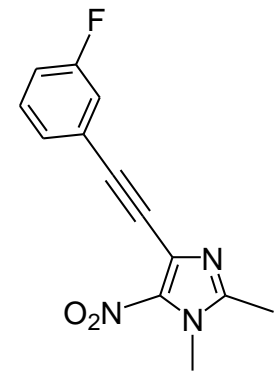

80

70

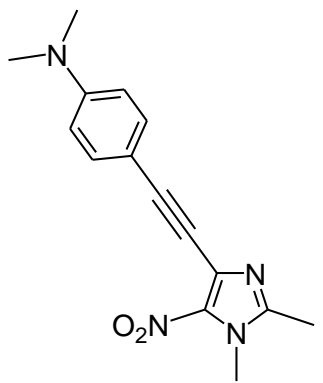

81

40

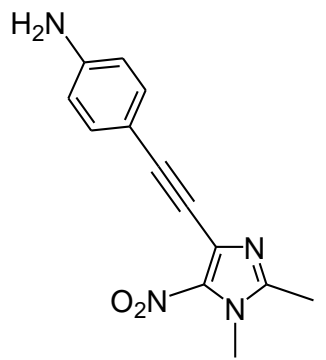

82

98

${ }^{\mathrm{a} C}$ Conditions: $\mathrm{Pd}\left(\mathrm{PPh}_{3}\right)_{4}\left(0.05\right.$ equiv.); $\mathrm{CuI}\left(0.1\right.$ equiv.); alkyne (2.0 equiv.) and $\mathrm{Bu}_{4} \mathrm{NOAc}(1.1$ equiv.) in MeCN under microwave irradiation $\left(60^{\circ} \mathrm{C}\right)$.

Despite numerous trials, no combination of the previous parameters was successful for 3 terminal alkynes: 1 phenylprop-2-yn-1-ol, prop-2-ynylbenzene and phenyl(prop-2-ynyl)sulfane.

\section{Synthesis of novel nitroimidazoles via electron transfer reactions}

\section{IV.A. Long-Distance $S_{\mathrm{RN}} 1\left(\mathrm{LD}-\mathrm{S}_{\mathrm{RN}} 1\right)$ in 5-nitroimidazole series}

To increase our knowledge of the reactivity of $\mathrm{LD}-\mathrm{S}_{\mathrm{RN}} 1$ and its limitations in 5-nitroimidazole series, and within the framework of our research on the preparation of new potentially less toxic nitroimidazoles (less cytotoxic and less mutagenic), we prepared 4(5)-[4-(chloromethyl)phenyl]-1,2-dimethyl-5(4)-nitro-1 $H$ imidazoles and studied their reactivities with different nucleophiles in $\mathrm{S}_{\mathrm{RN}} 1$ experimental conditions (LD-S $\mathrm{S}_{\mathrm{RN}} 1$ ) in order to determine the reactivity of both isomers.

4-[4-(Chloromethyl)phenyl]-1,2-dimethyl-5-nitro-1H-imidazole, which appeared to be a good candidate to study LD-S $S_{\mathrm{RN}} 1$ reactivity, was obtained by bromination of 2-methyl-4(5)-nitro-1H-imidazole by action of dibrome in DMF, methylation by dimethylsulfate, Suzuki-Miyaura cross-coupling reaction [58] and chlorination by thionyl chloride (Scheme 14) [64]. 


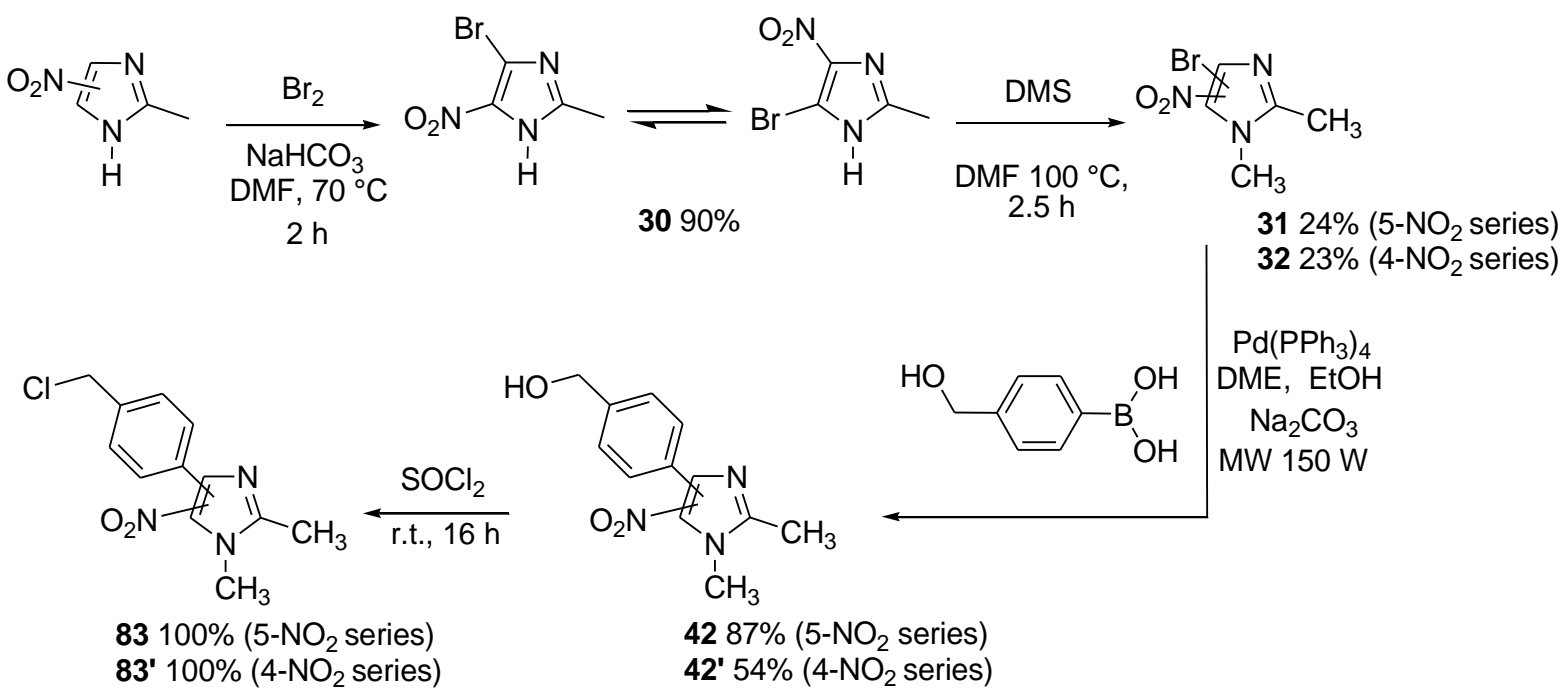

Scheme 14.Preparation of alkylating agents 83 and 83'.

Furthermore, as ammonium chlorides are known to be poor leaving groups in $\mathrm{S}_{\mathrm{N}} 2$ reactions[119-126], we decided to synthesize and to study the reactivity of $N$-[4-(1,2-dimethyl-5-nitro- $1 H$-imidazol-4-yl)benzyl]- $N, N$ diethylethanaminium chloride $\mathbf{8 4}$ which was prepared in 94\% yield from 4-[4-(chloromethyl)phenyl]-1,2dimethyl-5-nitro- $1 \mathrm{H}$-imidazole $\mathbf{8 3}$ with two equiv. of triethylamine in anhydrous acetone at $44{ }^{\circ} \mathrm{C}$ for $24 \mathrm{~h}$ (Scheme 15).<smiles>Cc1nc(-c2ccc(CCl)cc2)c([N+](=O)[O-])n1C</smiles>

83<smiles>CCN(CC)CC</smiles>

2 equiv. anhydrous acetone

$44^{\circ} \mathrm{C}, 24 \mathrm{~h}$<smiles>CC[N+](CC)(CC)Cc1ccc(-c2nc(C)n(C)c2[N+](=O)[O-])cc1</smiles>

$8494 \%$

Scheme 15.Preparation of alkylating agent 84 .

The first result shows that compound $\mathbf{8 3}$ reacts with the 2-nitropropane anion to give compound $\mathbf{8 7}$ alone, resulting from an $O$-alkylation following an $\mathrm{S}_{\mathrm{N}} 2$ mechanism in good yields under the classic $\mathrm{S}_{\mathrm{RN}} 1$ conditions described by Kornblum (65\% in DMSO and $72 \%$ in DMF) at room temperature. Various $\mathrm{S}_{\mathrm{RN}} 1$ experimental conditions were then tested, to study their influence on the reactivity. Under classic heating (heating by oil bath) in DMSO at $170{ }^{\circ} \mathrm{C}$, a mixture of expected products from $C$-alkylation 85 (36\%) and 86 (43\%), resulting consecutively from $C$-alkylation following an $\mathrm{S}_{\mathrm{RN}} 1$ mechanism and then via a base-promoted nitrous acid elimination, was obtained. In DMF at $140{ }^{\circ} \mathrm{C}$, the reaction led to compounds $85(57 \%)$ and 87 (12\%), but without any trace of compound 86. Indeed, DMSO should solvate counterions in 2-nitropropane anion sodium salt better than DMF, inducing higher base strength in the 2-nitropropane anion[127]. 
Table 4.LD-S $\mathrm{S}_{\mathrm{RN}} 1$ reactivity with 2-nitropropane anion and compounds 83 and 84.

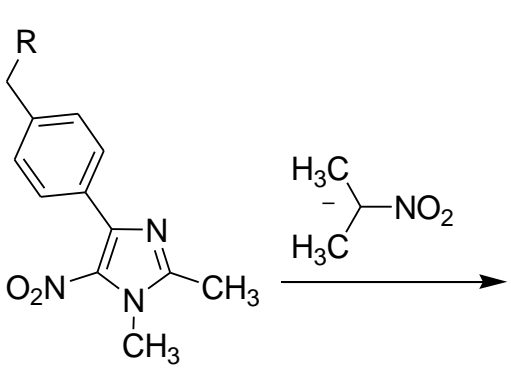

$83 \mathrm{R}=\mathrm{Cl}$

$$
84 \mathrm{R}=(\mathrm{Et})_{3} \mathrm{~N}^{+} \mathrm{Cl}^{-}
$$

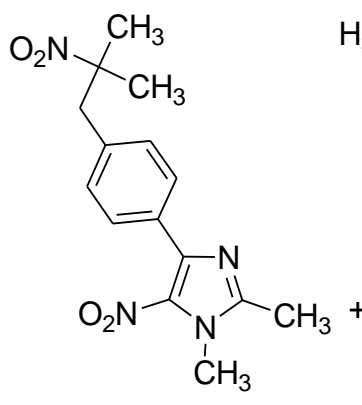

85<smiles>CC(C)=Cc1ccc(-c2nc(C)n(C)c2[N+](=O)[O-])cc1</smiles>

86<smiles>Cc1nc(-c2ccc(C=O)cc2)c([N+](=O)[O-])n1C</smiles>

87

\begin{tabular}{|c|c|c|c|c|c|c|c|c|}
\hline Entry & Product & Equiv. Anion & Solvent & $\mathrm{T}(\mathrm{h})$ & Conditions & $85(\%)$ & $86(\%)$ & $87(\%)$ \\
\hline 1 & 83 & 6 & DMF & 0.5 & $\mathrm{~N}_{2}$, darkness, $\mathrm{rt}$ & - & - & 73 \\
\hline 2 & 83 & 6 & DMF & 0.5 & $\mathrm{~N}_{2}, \mathrm{hv}, \mathrm{rt}$ & - & - & 72 \\
\hline 3 & 83 & 6 & DMF & 0.5 & $\begin{array}{l}\mathrm{N}_{2} \text {, darkness, } \\
140^{\circ} \mathrm{C}\end{array}$ & 56 & - & - \\
\hline 4 & 83 & 6 & DMF & 0.5 & $140{ }^{\circ} \mathrm{C}$ & 57 & - & 12 \\
\hline 5 & 83 & 6 & DMF & 0.5 & $\mathrm{MW} 140{ }^{\circ} \mathrm{C}$ & 60 & 10 & 22 \\
\hline 6 & 83 & 3 & DMSO & 0.5 & $\mathrm{~N}_{2}, \mathrm{hv}, \mathrm{rt}$ & - & - & 62 \\
\hline 7 & 83 & 6 & DMSO & 0.5 & $\begin{array}{l}\mathrm{N}_{2} \text {, darkness, } \\
170^{\circ} \mathrm{C}\end{array}$ & 28 & 33 & traces \\
\hline 8 & 83 & 6 & DMSO & 0.5 & $170{ }^{\circ} \mathrm{C}$ & 36 & 43 & - \\
\hline 9 & 83 & 6 & DMSO & 0.5 & $\mathrm{MW} 170{ }^{\circ} \mathrm{C}$ & - & 60 & - \\
\hline 10 & 84 & 3 & DMSO & 48 & $\mathrm{~N}_{2}, \mathrm{hv}, \mathrm{rt}$ & - & - & 22 \\
\hline 11 & 84 & 6 & DMF & 0.5 & $\mathrm{MW} 140{ }^{\circ} \mathrm{C}$ & 44 & 32 & - \\
\hline
\end{tabular}

On the basis of these encouraging results and previous studies[128-133], we decided to estimate the influence that microwave irradiation might have on the $\mathrm{LD}-\mathrm{S}_{\mathrm{RN}} 1$ reaction. The best microwave-assisted experimental conditions were defined and led in DMF to a mixture of compounds $\mathbf{8 5}(60 \%), \mathbf{8 6}(10 \%)$ and 87 (22\%)(Table 4, entry 5) [63]. In DMSO, these conditions led to the formation of compound 86in $60 \%$ yield (Entry 9). Thus, no "special effect" (non-thermal effect) resulting from the microwave irradiation was observed and only the thermal effect seems to influence the main mechanism (from $S_{N} 2$ to $S_{R N} 1$ ). Furthermore, no trace of aldehyde appeared to be formed. Therefore, these results suggest that both substrates $\mathbf{8 3}$ and $\mathbf{8 4}$ form $C$-alkylated products by an $\mathrm{S}_{\mathrm{RN}} 1$ mechanism. To confirm this mechanism by single electron transfer, reactions of inhibition were performed by adding to the reaction mixture catalytic quantities $(10 \mathrm{~mol} \%)$ of cupric chloride $\left(\mathrm{CuCl}_{2}\right)$ or 2,2,6,6-tetramethyl-1-piperidinyloxyle (TEMPO), inhibitors usually used in mechanistic studies to prove $S_{\mathrm{RN}} 1$ mechanisms. Reaction times for the reactions of inhibition are identical to those of Table 4 , entry 5 without inhibitors. 
Table 5.Inhibition Reactions with 2-Nitropropane Aniona

\begin{tabular}{lllll}
\hline Entry & Inhibitor & $\mathbf{8 5}(\%)$ & $\mathbf{8 6}(\%)$ & $\mathbf{8 7}(\%)$ \\
\hline 1 & $(0.1$ equiv) & & & 22 \\
2 & - & 60 & 10 & 22 \\
3 & $\mathrm{CuCl}_{2}$ & 25 & 10 & 27
\end{tabular}

\begin{abstract}
${ }^{a}$ All reactions were performed using 1 equiv. of 83, 6 equiv. of 2-nitropropane anion in DMF under microwave irradiations at $140{ }^{\circ} \mathrm{C}$, for $0.5 \mathrm{~h}$.

Formation of compound $\mathbf{8 5}$ was observed to be inhibited with TEMPO and $\mathrm{CuCl}_{2}$. The effects of the classic inhibitors in the reaction between compound $\mathbf{8 3}$ and the 2-nitropropane anion are proof of an $\mathrm{S}_{\mathrm{RN}} 1$ mechanism for this $C$-alkylation reaction. To extend the reaction to other nucleophiles, we studied anions centered on the sulfur atom(Scheme 16). The reaction between sodium 4-methylbenzenesulfinate and substrate 83 in DMSO at $100{ }^{\circ} \mathrm{C}$ under microwave irradiation led to $S$-alkylated compound $\mathbf{8 8}$ in good yields (79\%).
\end{abstract}

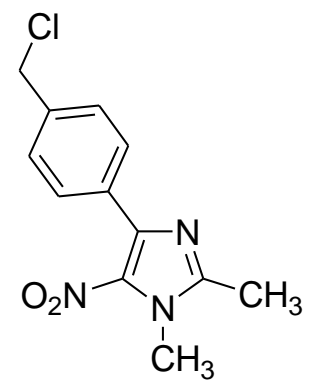

83

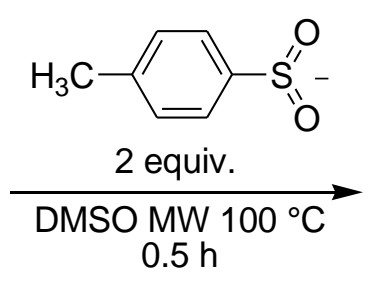

$\mathrm{H}_{3} \mathrm{C}$<smiles>Cc1ccc(S(=O)(=O)Cc2ccc(-c3nc(C)n(C)c3[N+](=O)[O-])cc2)cc1</smiles>

$8879 \%$

Scheme 16.Reactivity of $\mathbf{8 3}$ with sodium 4-methylbenzenesulfinate.

In order to identify the main mechanism of this reaction, the reactivity of the latter was studied by adding an inhibitor (Table 6, entries 2 and 3).

Table 6.Inhibition Reaction with Sodium 4-Methylbenzenesulfinate ${ }^{\mathrm{a}}$.

\begin{tabular}{lll}
\hline Entry & Inhibitor $(0.1$ equiv. $)$ & $\mathbf{4 4}(\%)$ \\
\hline 1 & - & 79 \\
2 & $\mathrm{CuCl}_{2}$ & 55 \\
3 & TEMPO & 46
\end{tabular}

\footnotetext{
all reactions were performed using 1 equiv. of $\mathbf{8 3}, 2$ equiv. of sodium 4-methylbenzene-sulfinate in DMSO under microwave irradiation at $100{ }^{\circ} \mathrm{C}$, for $0.5 \mathrm{~h}$.

The decrease in the reaction rate is less significant than with the 2-nitropropane anion and indicates that the reaction may follow a combination of $S_{N} 2$ and $S_{R N} 1$ mechanisms.
} 


\section{IV.B. Tetrakis(dimethylamino)ethylene (TDAE) methodology in 5- nitroimidazole series}

Tetrakis(dimethylamino)ethylene (TDAE) is a reducing agent which reacts with halogenated derivatives to generate an anion in soft conditions by means of two sequential transfers of one electron[134-136]. We showed that from $o$ - or $p$-nitrobenzyl chlorides, TDAE was able to generate a nitrobenzylic carbanion capable of reacting with various electrophiles[137].Since 2003 and by means of this strategy, we have developed several reactions between nitrobenzylic substrates, heterocyclic or quinonic and carbonylated electrophile series such as aldehydes [137-140], ketones [137-140], $\alpha$-ketoesters [141-143], $\alpha$-ketolactames [144], $\alpha$-diketones [145, 146] and diethyl ketomalonate [141-143], leading to adducts of the corresponding alcohol. In line with our program on the study of electron transfer reactions of bioreducible alkylating agents and the preparation of new nitroimidazoles with biological potential, we synthesized new highly functionalized 5-nitro- $1 \mathrm{H}$-imidazoles from 4-[4(chloromethyl)phenyl]-1,2-dimethyl-5-nitro-1H-imidazole $\mathbf{8 3}$ and various carbonylated aromatic derivatives or $\alpha$-carbonylated-ester by using the TDAE methodology. The reaction of compound $\mathbf{8 3}$ with 3 equiv. of diverse aromatic aldehydes 89a-j in the presence of TDAE, at $-20{ }^{\circ} \mathrm{C}$ for $1 \mathrm{~h}$, followed by $24 \mathrm{~h}$ at room temperature (Scheme 17), led to the corresponding derived alcohols 90a-j in moderate to good yields (24-78\%) (Table 7)[64].<smiles>[R]C([R])=O</smiles>

83

89a-m

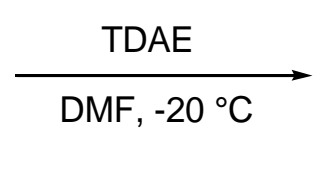<smiles>[R]C([R])(O)c1ccc(-c2nc(C)n(C)c2[N+](=O)[O-])cc1</smiles>

90a-m

Scheme 17. Reaction of compound 83 with various carbonylated compounds using TDAE methodology.

Table 7.Products and Yields of the Reaction of 83 with Various Carbonylated Compounds Using TDAE Methodology ${ }^{\mathbf{a}}$.

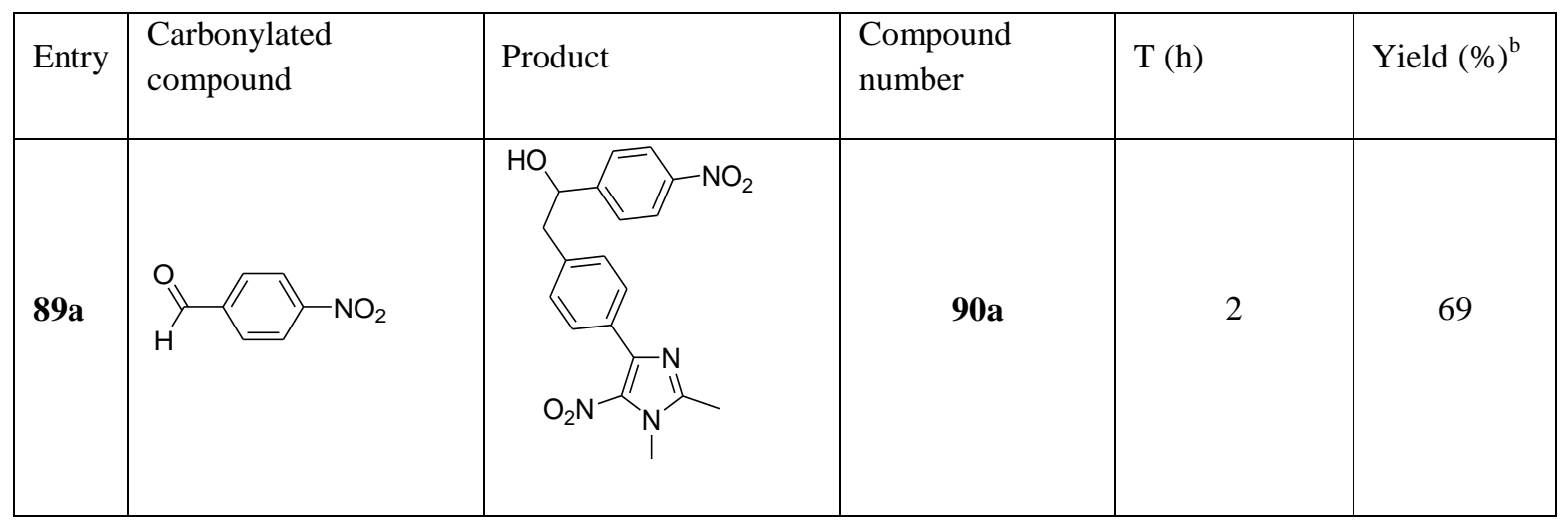




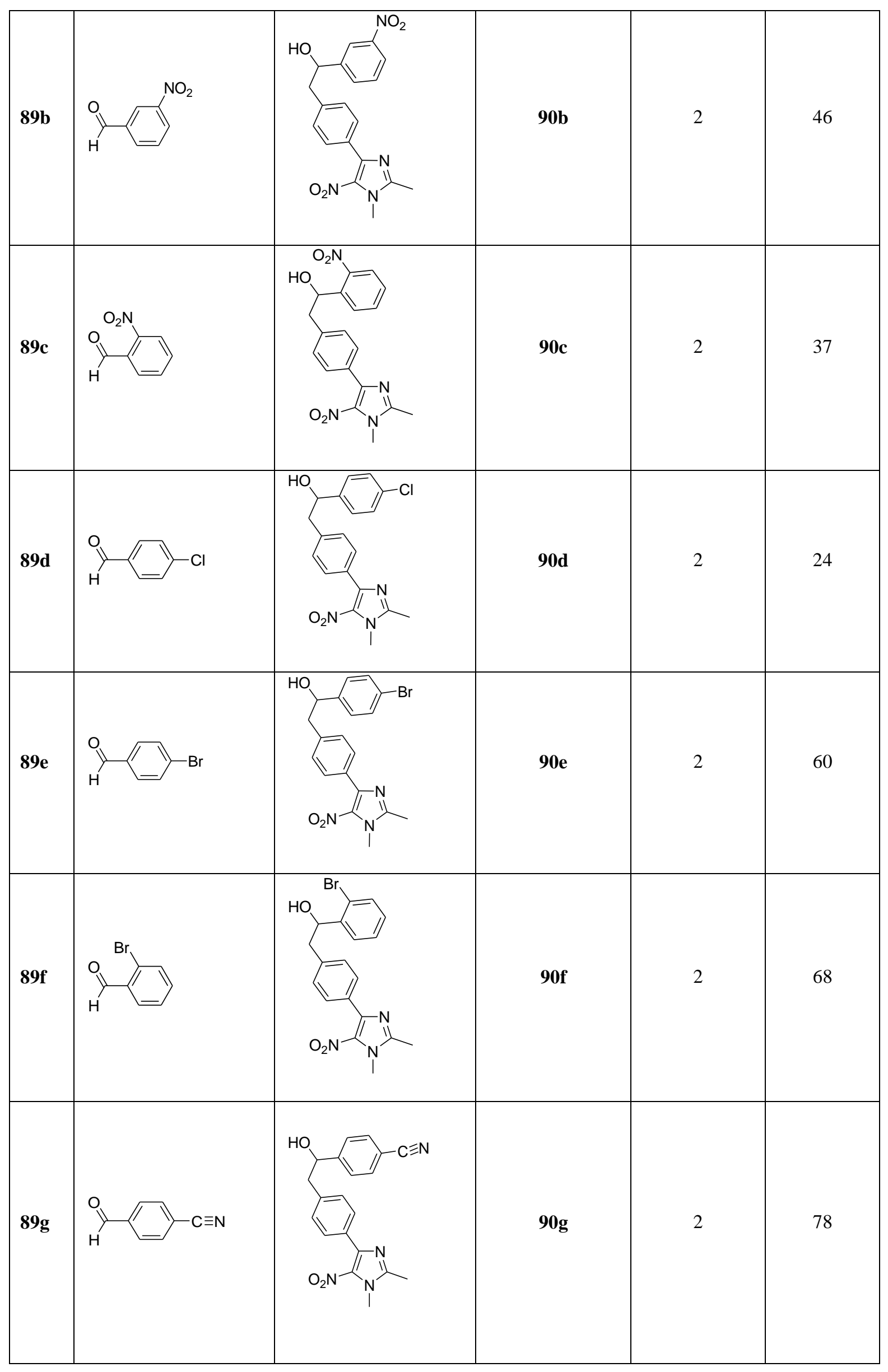




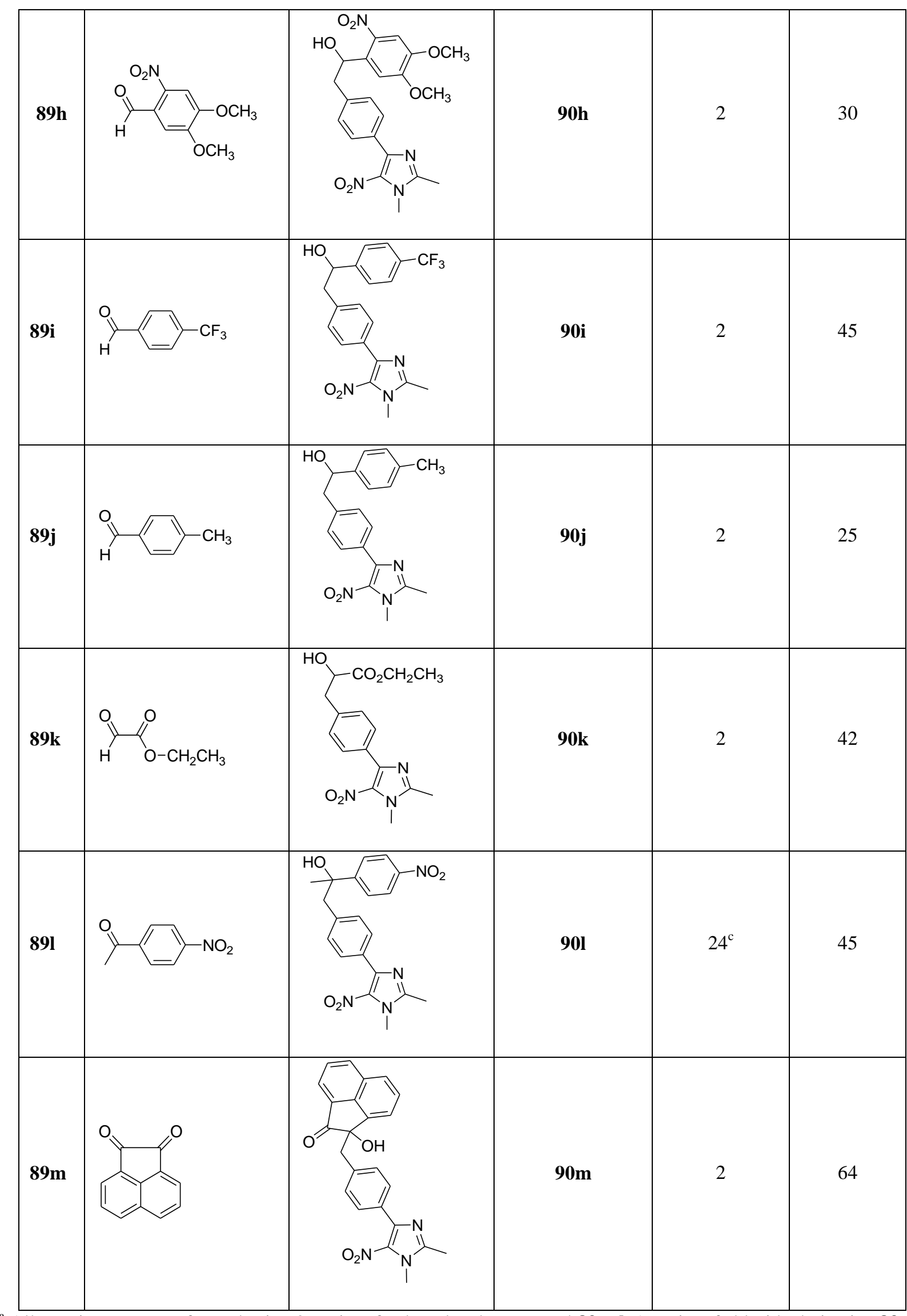

${ }^{\text {a }}$ All reactions were performed using 3 equiv. ofcarbonylated compound $\mathbf{8 9}$ a-l, 1 equiv. of chloride derivative $\mathbf{8 3}$ and 1 equiv. of TDAE in anhydrous DMF stirred at $-20{ }^{\circ} \mathrm{C}$ for $1 \mathrm{~h}$ and then warmed up to rt for $24 \mathrm{~h}$. ${ }^{\mathrm{b}}$ Yield relative to chloride $\mathbf{8 3}{ }^{\mathrm{c}}$ The reaction was performed using 3 equiv. of carbonyl compounds $\mathbf{8 9 m}, 1$ equiv. of 
chloride 83 and 1 equiv. of TDAE in anhydrous DMF stirred at $-20{ }^{\circ} \mathrm{C}$ for $1 \mathrm{~h}$ and then warmed up to $80{ }^{\circ} \mathrm{C}$ for $24 \mathrm{~h}$.

High yields were obtained with $p$-nitrobenzaldehyde (89a), o-bromobenzaldehyde (89f) and $p$ cyanobenzaldehyde $(\mathbf{8 9 g})$, whereas $p$-chlorobenzaldehyde $(\mathbf{8 9 d}), \quad p$-methylbenzaldehyde $(\mathbf{8 9 j})$ and 6nitroveratraldehyde $\mathbf{( 8 9 h )}$ produced low yields. This difference in yields could be explained by electronic effects: compounds bearing withdrawing groups gave the best yields, whereas those bearing electron-donating groups led to the lowest yields, while in the presence of halogen atoms, yields were variable. With compound 90d, the low yield obtained is likely to result from purification problems. With nitrobenzaldehydes derivatives, steric hindrances could explain the difference between $o$-and $m$-nitrobenzaldehyde (37\% vs 46\%). We also studied the reaction between compound $\mathbf{8 3}$ and $\alpha$-ketoester derivatives as ethyl glyoxylate $(\mathbf{8 9 k}), \alpha$-diketone derivatives such as acenaphtenedione $(\mathbf{8 9} \mathbf{m})$ and ketones such as $p$-acetophenone (891) and we obtained corresponding hydroxylated derivatives $\mathbf{9 0 k - m}$ in moderate to good yields (42-64\%)(Table 7). Just as in $p$-nitrobenzylic series, because of its low reactivity, the use of $p$-acetophenone (89l) required heating for $24 \mathrm{~h}$ at $80{ }^{\circ} \mathrm{C}$ to lead to the end of the reaction.

\section{CONCLUSION}

The 5-nitroimidazoles continue to be the drugs of choice for treating parasitic and bacterial infections, in spite of the mutagenicity and development of resistance observed with metronidazole. In our attempts to develop new molecules which might offer advantages in clinical use over the well-established metronidazole, we have explored new strategies of synthesis: VNS reaction, palladium-catalyzed cross-coupling reactions (SuzukiMiyaura, $O$-arylation of an aryl fluoride, Sonogashira) and electron transfer reactions (LD-S $\mathrm{RN}_{\mathrm{R}} 1$, TDAE methodology). These new 5-nitroimidazoles hold promise for the development of drugs that can meet the principal challenge to obtain a reasonable degree of activity (in particular against metronidazole-resistant strains) and an absence of mutagenicity.

\section{CONFLICT OF INTEREST}

The authors confirm that the article content has no conflict of interest.

\section{ACKNOWLEDGEMENTS}

The authors are grateful to Dr Christophe Curti for fruitful discussions.

\section{REFERENCES}

[1] Maeda, K.; Osato, T.; Umezawa, H. A new antibiotic, azomycin. J. Antibiot., Ser. A.,1953, 6, 182.

[2] Nakamura, S. Structure of azomycin, a new antibiotic.Pharm. Bull.,1955, 3, 379-383.

[3] Horie, H. Anti-trichomonas effect of azomycin. J. Antibiot., Ser. A.,1956, 9, 168.

[4] Despois, R.; Pinnert-Sindico, S.; Ninet, L.; Preud'homme, J.Three antibiotics of different groups produced by the same strain of Streptomyces.Giorn. Microbiol., 1956, 21,76-90.

[5] Polak, A.; Richle, R. Mode of action of the 2-nitroimidazole derivative benznidazole. Ann. Trop. Med. Parasitol.,1978, 72, 45-54.

[6] Calvo, K. L.; Ronco, M. T.; Noguera, N. I.; Garcia, F. Benznidazole modulates cell proliferation in acute leukemia cells. Immunopharmacol. Immunotoxicol.,2013, 35, 478-486.

[7] Maltzman, J. S.; Koretzky, G. A. Azathioprine: old drug, new actions. J. Clin. Invest., 2003, 111, 1122-1124 and references herein.

[8] Bourdin Trunz, B.; Jędrysiak, R.; Tweats, D.; Brun, R.; Kaiser, M.; Suwiński, J.; Torreele, E. 1-Aryl4-nitro-1H-imidazoles, a new promising series for the treatment of human African trypanosomiasis. Eur. J. Med.Chem.,2011, 46, 1524-1535.

[9] Rosenblatt, J. E.; Edson, R. S. Metronidazole. Mayo. Clin. Proc., 1987, 62, 1013-1017. 
[10] Jorgensen, M. A.; Manos, J.; Mendz, G. L.; Hazell, S. L. The mode of action of metronidazole in Helicobacter pylori: futile cycling or reduction? J. Antimicrob. Chemother., 1998, 41, 67-75.

[11] Benakli, K.; Terme, T.; Vanelle, P.Synthesis of new active sulfones in the 5-nitroimidazole series.Molecules, 2002, 7, 382-385.

[12] Citron, D. M.; Tyrrell, K. L.; Warren, Y. A.; Fernandez, H.; Merriam, C. V.; Goldstein, E. J. C. In vitro activities of tinidazole and metronidazole against Clostridium difficile, Prevotella bivia and Bacteroides fragilis. Anaerobe, 2005, 11, 315-317.

[13] Kim, P.; Zhang, L.; Manjunatha, U. H.; Singh, R.; Patel, S.; Jiricek, J.; Keller, T. H.; Boshoff, H. I.; Barry, C. E. III; Dowd, C. S.Structure-activity relationships of antitubercular nitroimidazoles. 2. Determinants of aerobic activity and quantitative structure-activity relationships. J. Med. Chem.,2009, 52, 1329-1344.

[14] Upcroft, P.; Upcroft, J. A.Drug targets and mechanisms of resistance in the anaerobic protozoa.Clin. Microbiol. Rev.,2001, 14, 150-164.

[15] Jacob, R. M.; Régnier, G. L.; Crisan, C. Nitroimidazolealkanols and acyl derivatives. US Patent 2944061, July 5, 1960; Chem. Abstr. 1961, 55, 1657.

[16] Cosar, C.; Crisan, C.; Horclois, R.; Jacob, R. M.; Robert, J.; Tchelitcheff, S.; Vaupré, R. Nitroimidazoles. Arzneim.-Forsch.,1966, 16, 23-29.

[17] Miller, M. W.; Howes, H. L.; Kasubick, R. V.; English, A. R. Alkylation of 2-methyl-5nitroimidazole. Some potent antiprotozoal agents.J. Med. Chem.,1970, 13, 849-852.

[18] Hoffer, M.; Grunberg, E.Synthesis and antiprotozoal activity of 1-(3-chloro-2-hydroxypropyl)substituted nitroimidazoles.J. Med. Chem.,1974, 17, 1019-1020.

[19] Ross, W. J.; Jamieson, W. B.; McCowen, M. C.Antiparasitic nitroimidazoles. 1. Some 2-styryl-5nitroimidazoles.J. Med. Chem.,1972, 15, 1035-1040.

[20] Petri, W. A. Jr.Therapy of intestinal protozoa.Trends. Parasitol.,2003, 19, 523-526.

[21] Rustia, M.; Shubik, P. Induction of lung tumors and malignant lymphomas in mice by metronidazole. J. Natl. Cancer Inst., 1972, 48, 721-729.

[22] Shubik, P. Current status of chemical carcinogenesis. Proc. Natl. Acad. Sci.,1972, 69, 1052-1055.

[23] Legator, M. S.; Connor, T. H.; Stoeckel, M. Detection of mutagenic activity of metronidazole and niridazole in body fluids of humans and mice. Science, 1975, 188, 1118-1119.

[24] Walsh, J. S.; Wang, R.; Bagan, E.; Wang, C. C.; Wislocki, P.; Miwa, G. T.Structural alterations that differentially affect the mutagenic and antitrichomonal activities of 5-nitroimidazoles. J. Med. Chem., 1987, 30, 150-156.

[25] Jentzer, O.; Vanelle, P.; Crozet, M. P.; Maldonado, J.; Barreau, M. Nouveaux 5-nitroimidazoles à noyau lactame hautement actifs : préparation et propriétés antibactériennes.Eur. J. Med. Chem.,1991, 26, 687-697.

[26] Vanelle, P.; Maldonado, J.; Gasquet, M.; Delmas, F.; Timon-David, P.; Jentzer, O.; Crozet, M. P. Studies on antiparasitic agents: Effect of the lactam nucleus substitution in the 2-position on the in vitro activity of new 5-nitroimidazoles. J. Pharm. Pharmacol.,1991, 43, 735-736.

[27] Upcroft, J. A.; Campbell, R. W.; Benakli, K.; Upcroft, P.; Vanelle, P. Antimicrob. Agents Chemother., 1999, 43, 73-76.

[28] Vanelle, P.; Crozet, M. P.; Maldonado, J.; Barreau, M. Synthèse par réactions $\mathrm{S}_{\mathrm{RN}} 1$ de nouveaux 5nitroimidazoles antiparasitaires et antibactériens.Eur. J. Med. Chem.,1991, 26, 167-178.

[29] De Méo, M.; Vanelle, P.; Bernadini, E.; Laget, M.; Maldonado, J.; Jentzer, O.; Crozet, M. P.; Duménil, G.Evaluation of the mutagenic and genotoxic activities of 48 nitroimidazoles and related imidazole derivatives by the Ames test and the SOS Chromotest.Env. Molec. Mutagen.,1992, 19, 167-181.

[30] Upcroft, J. A.; Dunn, L. A.; Wright, J. M.; Benakli, K.; Upcroft, P.; Vanelle, P. 5-nitroimidazole drugs effective against metronidazole-resistant Trichomonas vaginalis and Giardia duodenalis. Antimicrob. Agents Chemother., 2006, 50, 344-347.

[31] Crozet, M. D.; Botta, C.; Gasquet, M.; Curti, C.; Rémusat, V.; Hutter, S.; Chapelle, O.; Azas, N.; De Méo, M.; Vanelle, P. Lowering of 5-nitroimidazole's mutagenicity: Towards optimal antiparasitic pharmacophore.Eur. J. Med. Chem.,2009, 44, 653-659. 
[32] Dunn, L. A.; Tan, K. S.; Vanelle, P.; Juspin, T.; Crozet, M. D.; Terme, T.; Upcroft, P.; Upcroft, J. A. Development of metronidazole-resistant lines of Blastocystis sp. Parasitol. Res., 2012, 1, 441-450.

[33] Torreele, E.; Bourdin Trunz, B.; Tweats, D.; Kaiser, M.; Brun, R.; Mazué, G.; Bray, M. A.; Pécoul, B.Fexinidazole - a new oral nitroimidazole drug candidate entering clinical development for the treatment of sleeping sickness.PLoS NTD, 2010, 4, e923.

[34] Olsson-Liljequist, B.; Nord, C. E. In vitro susceptibility of anaerobic bacteria to nitroimidazoles. Scand. J. Infect. Dis., Suppl., 1981, 26, 42-45.

[35] Halliwell, B. J. In: Free radicals in biology and medicine, Gutteridge; M. C. Ed.; Clarendon Press: Oxford, 1986, 238.

[36] Sharma, R. Nitroimidazole radiopharmaceuticals in hypoxia: Part II cytotoxicity and radiosensitization applications. Curr. Radiopharm.,2011, 4, 379-393.

[37] Townson, S. M.; Hanson, G. R.; Upcroft, J. A.; Upcroft, P.A purified ferredoxin from Giardia duodenalis.Eur. J. Biochem., 1994, 220, 439-446.

[38] Townson, S. M.; Upcroft, J. A.; Upcroft, P.Characterization and purification of pyruvate:ferredoxin oxidoreductase from Giardia duodenalis.Mol. Biochem. Parasitol.,1996, 79, 183-193.

[39] Dunn, L. A.; Burgess, A. G.; Krauer, K. G.; Eckmann, L.; Vanelle, P.; Crozet, M. D.; Gillin, F. D.; Upcroft, P.; Upcroft, J. A. A new-generation 5-nitroimidazole can induce highly metronidazoleresistant Giardia lamblia in vitro.Int. J. Antimicrob. Agents.,2010, 36, 37-42.

[40] Leitsch, D.; Kolarich, D.; Wilson, I. B. H.; Altmann, F.; Duchêne, M. Nitroimidazole action in Entameba histolytica: A central role for thioredoxin reductase. PLoS Biol.,2007, 5, 1820-1834.

[41] Leitsch, D.; Kolarich, D.; Binder, M.; Stadlmann, J.; Altmann, F.; Duchêne, M.Trichomonas vaginalis: Metronidazole and other nitroimidazole drugs are reduced by the flavin enzyme thioredoxin reductase and disrupt the cellular redox system. Implications for nitroimidazole toxicity and resistance. Mol. Microbiol.,2009, 72, 518-536.

[42] Rasoloson, D.; Vanácová, S.; Tomková, E.; Rázga, J.; Hrdy, I.; Tachezy’, J.; Jaroslav, K.Mechanisms of in vitro development of resistance to metronidazole in Trichomonas vaginalis.Microbiology,2002, 148, 2467-2477.

[43] Pal, D.; Banerjee, S.; Cui, J.; Schwartz, A.; Ghosh, S. K.; Samuelson, J. Giardia, Entamoba, and Trichomonas enzymes activate metronidazole (nitroreductases) and inactivate metronidazole (nitroimidazole reductases). Antimicrob. AgentsChemother., 2009, 53, 458-464.

[44] Van Amsterdam, K.; Bart, A.; Van der Ende, A. A Helicobacter pylori TolC efflux pump confers resistance to metronidazole. Antimicrob. Agents Chem.,2005, 49, 1477.

[45] Golinski, J.; Makosza, M.; Rykowski, A. Formation of aziridine and cyclopropane rings in reaction of quinozalines and naphthyridines with $\alpha$-halocarbanions.Tetrahedron Lett.,1983, 24, 3279-3280.

[46] Makosza, M.; Chylinska, B.; Mudryk, B. Reactions of organic anions. 113. Vicarious nucleophilic substitution of hydrogen in nitropyridines by $\alpha$-chloroalkyl phenyl sulfone carbanions. Liebigs Ann. Chem., 1984, (1), 8-14.

[47] Makosza, M.; Kinowski, A.J.; Danikiewicz, W.; Mudryk, B. Reactions of organic anions. Part 134. Vicarious nucleophilic substitution in nitroquinolines.Liebigs Ann. Chem.,1986, (1), 69-77.

[48] Makosza, M.; Slomka, E. Reactions of organic anions. 118. Vicarious nucleophilic substitution of hydrogen in nitro derivatives of 5-membered aromatic heterocycles. Bull. Pol. Ac.: Chem.,1984, 32, 69-74.

[49] Makosza, M.; Kwast, E. Reactions of organic anions. Part 143. Vicarious nucleophilic substitution of hydrogen in imidazole derivatives. Bull. Pol. Ac.: Chem.,1987, 35, 287-292.

[50] Bosco, M.; Forlani, L.; Liturri, V.; Riccio, P.;Todesco, P. E.Reactivity of 2-halothiazoles towards nucleophiles: kinetics and mechanisms of the reactions of 2-halothiazoles with benzenethiolate ion.J. Chem. Soc. B. Phys. Org., 1971,(7), 1373-1376.

[51] Makosza, M.; Golinski, J.; Baran, J.Reactions of organic anions. Part 109. Vicarious nucleophilic substitution of hydrogen in nitroarenes with carbanions of alpha-haloalkyl phenyl sulfones.J. Org. Chem.,1984, 49, 1488-1494.

[52] Crozet, M. D.; Rémusat, V.; Curti, C.; Vanelle, P. Rapid synthesis of new 5-nitroimidazoles as potential antibacterial drugs via VNS procedure.Synth. Commun.,2006, 36, 3639-3646. 
[53] Antane, S.; Bernotas, R.; Li, Y.; McDevitt, R.; Yan, Y. Chloromethyl sulfones from sulfonyl chlorides via a one-pot procedure.Synth. Commun.,2004, 34, 2443-2449.

[54] Makosza, M. In: Current Trends in Organic Synthesis; Nozaki, H., Ed. Pergamon Press: Oxford, 1983, 401.

[55] Sunjic, V.; Fajdiga, T.; Japelj, M.; Rems, P. Nucleophilic substitutions in some derivatives of 4-and 5-nitroimidazoles. J. Heterocycl. Chem.,1969, 6, 53-60.

[56] Bhujanga Rao, A. K. S.; Gundu Rao, C.; Singh, B. B.A new high-yielding method for the preparation of 2-alkyl- and 1,2-dialkyl-4-nitro-5-bromoimidazoles.J. Org. Chem.,1992, 57, 32403242.

[57] Crozet, M. D.; Castera-Ducros, C.; Vanelle, P. An efficient microwave-assisted Suzuki crosscoupling reaction of imidazo[1,2-a]pyridines in aqueous medium. Tetrahedron Lett.,2006, 47, 70617065 .

[58] Crozet, M. D.; Zink, L.; Rémusat, V.; Curti, C.; Vanelle, P. Efficient microwave-assisted palladiumcatalyzed Suzuki-Miyaura cross-coupling reactions in 5-nitroimidazole series.Synthesis, 2009, (18), 3150-3156.

[59] Ellis, G. P.; Epstein, C.; Fitzmaurice, C.; Golberg, L.; Lord, G. H. Synthesis and antiprotozoal activity of some nitro-(nitroaryl)imidazoles. J. Pharm. Pharmacol.,1967, 19, 102-107.

[60] Vanelle, P.; Crozet, M. P. Recent advances in the chemical synthesis of novel nitroimidazoles via electron transfer reactions. Recent Res. Devel. in Organic Chem.,1998, 2, 547-566.

[61] Crozet, M. D.; Perfetti, P.; Kaafarani, M.; Vanelle, P.; Crozet, M. P. A new synthetic approach for novel 4-substituted-5-nitroimidazoles.Tetrahedron Lett.,2002, 43, 4127-4129.

[62] Crozet, M. D.; Perfetti, P.; Kaafarani, M.; Crozet, M. P.; Vanelle, P. Rapid syntheses of nitroheterocycles that bear a diethyl methylenemalonate group $\beta$ to a nitro group.Lett. Org. Chem.,2004, 1, 326-330.

[63] Zink, L.; Crozet, M. D.; Terme, T.; Vanelle, P. Long distance-S $\mathrm{RN}_{\mathrm{RN}} 1$ in nitroimidazole series favored by temperature.Tetrahedron Lett.,2011, 52, 6991-6996.

[64] Juspin, T.; Zink, L.; Crozet, M. D.; Terme, T.; Vanelle, P. High functionalization of 5-nitro-1Himidazole derivatives: The TDAE approach.Molecules, 2011, 16, 6883-6893.

[65] Buckingham, J. Dictionary of Natural Products; University Press: Cambridge, MA, 1994.

[66] Czarnik, A. W. Guest editorial. Acc. Chem. Res., 1996, 29,112-113.

[67] Theil, F. Synthesis of diaryl ethers: A long-standing problem has been solved. Angew. Chem. Int. Ed.,1999, 38, 2345-2347.

[68] Sawyer, J. S. Recent advances in diaryl ether synthesis.Tetrahedron,2000, 56, 5045-5065.

[69] Muci, A. R.; Buchwald, S. L.Practical palladium catalysts for C-N and C-O bond formation. Top. Curr. Chem.,2002, 219, 131-209.

[70] Ley, S. V.;Thomas, A. W. Modern synthetic methods for copper-mediated C(aryl)O, C(aryl)N, and C(aryl)S bond formation.Angew. Chem. Int. Ed.,2003, 42, 5400-5449.

[71] Cristau, P.; Vors, J.-P.; Zhu, J. Rapid and diverse route to natural product-like biaryl ether containing macrocycles.Tetrahedron, 2003, 59, 7859-7870.

[72] Chan, D. M. T.; Monaco, K. L.; Wang, R.-P.; Winters, M. P. New N- and O-arylations with phenylboronic acids and cupric acetate.Tetrahedron Lett.,1998, 39, 2933-2936.

[73] Evans, D. A.; Katz, J. L.; West, T. R. Synthesis of diaryl ethers through the copper-promoted arylation of phenols with arylboronic acids. An expedient synthesis of thyroxine.Tetrahedron Lett., 1998, 39, 2937-2940.

[74] Lam, P. Y. S.; Clark, C. G.; Saubern, S.; Adams, J.; Winters, M. P.; Chan, D. M. T.; Combs, A. New aryl/heteroaryl $\mathrm{C}-\mathrm{N}$ bond cross-coupling reactions via arylboronic acid/cupric acetate arylation.Tetrahedron Lett., 1998, 39, 2941-2944.

[75] Ullmann, F. Ueber eine neue bildungsweise von diphenylaminderivaten. Ber. Dtsch. Chem. Ges., 1903, 36, 2382-2386.

[76] Ullmann, F. Ueber eine neue darstellungsweise von phenyläthersalicylsäure. Ber. Dtsch. Chem. Ges., 1904, 37, 853-854.

[77] Ullmann, F.; Sponagel, P. Concerning the phenylisation of phenolene. Ber. Dtsch. Chem. Ges.,1905, 38, 2211-2212. 
[78] Lindley, J. Tetrahedron report number 163: Copper assisted nucleophilic substitution of aryl halogen.Tetrahedron,1984, 40, 1433-1456.

[79] Mann, G.; Hartwig, J. F. Palladium alkoxides: Potential intermediacy in catalytic amination, reductive elimination of ethers, and catalytic etheration. Comments on alcohol elimination from Ir(III).J. Am. Chem. Soc., 1996, 118, 13109-13110.

[80] Palucki, M.; Wolfe, J. P.; Buchwald, S. L. Palladium-catalyzed intermolecular Carbon-Oxygen bond formation: A new synthesis of aryl ethers.J. Am. Chem. Soc.,1997, 119, 3395-3396.

[81] Mann, G.; Hartwig, J. F. Palladium-catalyzed formation of diaryl ethers from aryl bromides. Electron poor phosphines enhance reaction yields.Tetrahedron Lett., 1997, 38, 8005-8008.

[82] Burgos, C. H.; Barder, T. E.; Huang, X.; Buchwald, S. L. Significantlyimproved method for the Pdcatalyzed coupling of phenols with aryl halides: Understanding ligand effects.Angew. Chem. Int. Ed.,2006, 45, 4321-4326.

[83] Zink, L.; Neildé, K.; Crozet, M. D.; Vanelle, P.Unexpected palladium catalyzed O-arylation occurring in 4-(4-fluoro-3-nitrophenyl)-1,2-dimethyl-5-nitro-1H-imidazole series.Tetrahedron Lett.,2012, 53, 5393-5397.

[84] Vanelle, P.; De Meo, M. P.; Maldonado, J.; Nouguier, R.; Crozet, M. P.; Laget, M.; Dumenil, G. Genotoxicity in oxazolidine derivatives: influence of the nitro group.Eur. J. Med. Chem.,1990, 25, 241-250.

[85] El-Kashef, H. S.; El-Emary, T. I.; Gasquet, M.; Timon-David, P.; Maldonado, J.; Vanelle, P. New pyrazolo[3,4-b]pyrazines: synthesis and biological activity.Pharmazie,2000, 55, 572-576.

[86] Gellis, A.; Kovacic, H.; Boufatah, N.; Vanelle, P.Synthesis and cytotoxicity evaluation of some benzimidazole-4,7-diones as bioreductive anticancer agents.Eur. J. Med. Chem.,2008, 43, 18581864.

[87] Cohen, A.; Crozet, M. D.; Rathelot, P.; Vanelle, P.An efficient aqueous microwave-assisted SuzukiMiyaura cross-coupling reaction in the thiazole series.Green Chem.,2009, 11, 1736-1742.

[88] Kabri, Y.; Azas, N.; Dumètre, A.; Hutter, S.; Laget, M.; Verhaeghe, P.; Gellis, A.; Vanelle, P. Original quinazoline derivatives displaying antiplasmodial properties.Eur. J. Med. Chem.,2010, 45, 616-622.

[89] Mutel, V.; Peters, J.-U.; Wichmann, J. Preparation of phenylethenyl or phenylethynyl derivatives as glutamate receptor antagonists. PCT Int. Appl. WO 2002046166, June 13, 2002; Chem. Abstr. 2002, $137,33292$.

[90] Buettelmann, B.; Ceccarelli, S. M.; Jaeschke, G.; Kolczewski, S.; Porter, R. H. P.; Vieira, E. Preparation of pyridin-4-ylethynylimidazoles and -pyrazoles as mGluR5a receptor antagonists. PCT Int. Appl. WO 2005118568, December 15, 2005; Chem. Abstr. 2005, 144, 51579.

[91] Jaeschke, G.; Lindemann, L.; Vieira, E.; Wichmann, J. Preparation of imidazole derivatives as mGluR5 antagonists and useful in the treatment of mGluR5 mediated diseases. PCT Int. Appl. WO 2011006910, January 20, 2011; Chem. Abstr. 2011, 154, 182550.

[92] Hanédanian, M.; Loreau, O.; Sawicki, M.; Taran, F. Synthèse et réactions $\mathrm{S}_{\mathrm{RN}} 1$ en série 3nitroimidazo[1,2-a]pyrimidine. Tetrahedron, 2005, 61, 2287-2294.

[93] Cao, H.; Zhong, H.; Lin, Y.; Yang, L. DABCO-catalyzed C-C bond formation reaction between electron-deficient alkynes and 1,3-dicarbonyl compounds.Tetrahedron,2012, 68, 4042-4047.

[94] Kourra, C.; Klotter, F.; Sladojevich, F.; Dixon, D. J. Alkali base-initiated Michael addition/alkyne carbocyclization cascades.Org. Lett.,2012, 14, 1016-1019.

[95] Kolb, H. C.; Finn, M. G.; Sharpless, K. B. Click chemistry: Diverse chemical function from a few good reactions.Angew.Chem. Int. Ed.,2001, 40, 2004-2021.

[96] Roche, M.; Terme, T.; Vanelle, P. First Long-Distance $\mathrm{S}_{\mathrm{RN}} 1$ on a propargylic chloride.Tetrahedron, Lett.2012, 53, 4184-4187.

[97] Roche, M.; Terme, T.; Vanelle, P. Original TDAE strategy using propargylic chloride: Rapid access to 1,4-diarylbut-3-ynol derivatives.Molecules, 2013, 18, 1540-1548.

[98] Hiroya, K.; Suzuki, N.; Yasuhara, A.; Egawa, Y.; Kasano, A.; Sakamoto, T. A new synthesis of aryl isothiocyanates: carbon disulfide as a dipolarophile. The reaction of (4,5,6,7-tetrahydro-2H-1,2,3- 
benzotriazolium-1-yl)arylaminide 1,3-dipoles with carbon disulfide: synthesis, kinetics, mechanism. Azolium 1,3-dipoles.J. Chem. Soc.,Perkin Trans. 1,2000, 4339-4346.

[99] Cramer, N.; Laschat, S.; Baro, A.; Schwalbe, H.; Richter, C. Enantioselective total synthesis of cylindramide.Angew. Chem., Int. Ed.,2005, 44, 820-822.

[100] Bang, H. B.; Han, S. Y.; Choi, D. H.; Yang, D. M.; Hwang, J. W.; Lee, H. S.; Jun, J.-G. Facile total synthesis of benzo[b]furan natural product XH-14. Synth. Commun.,2009, 39, 506-515.

[101] Bentoumi, W.; Helhaik, J.; Ple, G.; Ramondenc, Y.Pd-catalyzed regio and stereocontrolled mono and bis-coupling reactions of 1-bromo-6-chlorohexa-1,3,5-triene: synthesis of a naturally occurring tetraenynone.Tetrahedron,2009, 65, 1967-1970.

[102] Gung, B. W.; Omollo, A. O. A concise synthesis of R-(-)-cicutoxin, a natural 17-carbon polyenyne. Eur. J. Org. Chem.,2009, 1136-1138.

[103] Chang, C.-W.; Chein, R.-J. Absolute configuration of anti-HIV-1 agent (-)-concentricolide: Total synthesis of (+)-(R)-concentricolide.J. Org. Chem.,2011, 76, 4154-4157.

[104] Fischer, J.; Savage, G. P.; Coster, M. J. A Concise route to dihydrobenzo[b]furans: Formal total synthesis of (+)-lithospermic acid.Org. Lett.,2011, 13, 3376-3379.

[105] Zhang, F.; Zaidi, S.; Haney, K. M.; Kellogg, G. E.; Zhang, Y. Regio- and stereoselective syntheses of the natural product CCR5 antagonist anibamine and its three olefin isomers.J. Org. Chem.,2011, 76, 7945-7952.

[106] Doucet, H.; Hierso, J.-C. Palladium-based catalytic systems for the synthesis of conjugated enynes by Sonogashira reactions and related alkynylations.Angew. Chem., Int. Ed.,2007, 46, 834-871.

[107] Chinchilla, R.; Nájera, C. The Sonogashira reaction: A booming methodology in synthetic organic chemistry.Chem. Rev.,2007, 107, 874-922.

[108] Sakamoto, T.; Nagata, H.; Kondo, Y.; Shiraiwa, M.; Yamanaka, H.Palladium-catalyzed reactions of terminal acetylenes and olefins with halo-1,3-azoles.Chem. Pharm. Bull.,1987, 35, 823-828.

[109] Chittiboyina, A. G.; Reddy, C. R.; Watkins, E. B.; Avery, M. A. Addition of lithioimidazoles to isocyanates followed by Pd-coupling: access to 4-substituted imidazole-2,5dicarboxamides.Tetrahedron Lett.,2004, 45, 1869-1872.

[110] Lyaskovskyy, V.; Fröhlich, R.; Würthwein, E.-U. Aminobenzoannulated hetero- and carbocycles from 2-azahepta-2,4-dien-6-ynyllithium compounds: Scope and limitation of a novel benzoannulation reaction.Synthesis, 2007, (14), 2135-2144.

[111] Yamaguchi, E.; Shibahara, F.; Murai, T.1-Alkynyl- and 1-alkenyl-3-arylimidazo[1,5-a]pyridines: Synthesis, photophysical properties, and observation of a linear correlation between the fluorescent wavelength and Hammett substituent constants.J. Org. Chem.,2011, 76, 6146-6158.

[112] Appukkuttan, P.; Dehaen, W.; Van der Eycken, E. Transition-metal-free Sonogashira-type coupling reactions in water.Eur. J. Org. Chem.,2003, 4713-4716.

[113] Komáromi, A.; Tolnai, G.; Novák, Z.Copper-free Sonogashira coupling in amine-water solvent mixtures.Tetrahedron Lett.,2008, 49, 7294-7298.

[114] Bhattacharya, S.; Sengupta, S.Palladium catalyzed alkynylation of aryl halides (Sonogashira reaction) in water.Tetrahedron Lett.,2004, 45, 8733-8736.

[115] Leadbeater, N. E.; Tominack, B. J. Rapid, easy copper-free Sonogashira couplings using aryl iodides and activated aryl bromides.TetrahedronLett.,2003, 44, 8653-8656.

[116] Li, J.-H.; Liang, Y.; Xie, Y.-X. Efficient palladium-catalyzed homocoupling reaction and Sonogashira cross-coupling reaction of terminal alkynes under aerobic conditions.J. Org. Chem., 2005, 70, 4393-4396.

[117] Urgaonkar, S.; Verkade, J. G.Ligand-, copper-, and amine-free Sonogashira reaction of aryl iodides and bromides with terminal alkynes.J. Org. Chem.,2004, 69, 5752-5755.

[118] Neildé, K.; Crozet, M. D.; Terme, T.; Vanelle, P. Synthesis of 4-alkynyl-1,2-dimethyl-5-nitro-1Himidazoles via microwave-assisted Sonogashira cross-coupling reactions.Synthesis, 2013, 45, 13491356.

[119] Kornblum, N.; Pink, P.; Yorka, K. V.The leaving group as a factor in the alkylation of ambident anions.J. Am. Chem. Soc.,1961, 83, 2779-2780. 
[120] Crozet, M. P.; Archaimbault, G.; Vanelle, P.; Nouguier, R. Reactions $S_{\mathrm{RN}} 1$ en série hétérocyclique: IV: Réactivité des sels du diméthyl-2,2 nitro-5 dioxanne-1,3.Tetrahedron Lett.,1985, 26, 5133-5134.

[121] Vanelle, P.; Maldonado, J.; Madadi, N.; Gueiffier, A.; Teulade, J.-C.; Chapat, J.-P.; Crozet, M. P. $\mathrm{S}_{\mathrm{RN}} 1$ reactions in imidazo[1,2-a]pyridine series.Tetrahedron Lett.,1990, 31, 3013-3016.

[122] Crozet, M. P.; Giraud, L.; Sabuco, J.-F.; Vanelle, P.; Barreau, M. $\mathrm{S}_{\mathrm{RN}} 1$ reactions of a tetrasubstituted-1,4-benzoquinone. Tetrahedron Lett.,1991, 32, 4125-4128.

[123] Roubaud, C.; Vanelle, P.; Maldonado, J.; Crozet, M. P. Synthèse et réactions $\mathrm{S}_{\mathrm{RN}} 1$ en série 3nitroimidazo[1,2-a]pyrimidine.Tetrahedron, 1995, 51, 9643-9656.

[124] Crozet, M. P.; Gellis, A.; Pasquier, C.; Vanelle, P.; Aune, J.-P. Electron transfer reactivity in 5nitrouracil series. Tetrahedron Lett.,1995,36, 525-528.

[125] Gellis, A.; Vanelle, P.; Kaafarani, M.; Benakli, K.; Crozet, M. P.Synthèse et réactions $\mathrm{S}_{\mathrm{RN}} 1$ en série 5-nitrothiazole. Tetrahedron,1997, 53, 5471-5484.

[126] Rossi, R. A.; Pierini, A. B.; Peñéñori, A. B. Nucleophilic substitution reactions by electron transfer. Chem. Rev.,2003, 103, 71-167.

[127] Reichardt, C. In: Solvents and Solvent Effects in Organic Chemistry, 2nd ed.; VCH Verlagsgesellschaft: Weinheim, 1988, 5.

[128] Vanelle, P.; Gellis, A.; Kaafarani, M.; Maldonado, J.; Crozet, M. P. Fast electron transfer Calkylation of 2-nitropropane anion under microwave irradiation.Tetrahedron Lett.,1999, 40, 43434346.

[129] Gellis, A.; Njoya, Y.; Crozet, M. P.; Vanelle, P. Rapid synthesis of substituted imidazo[2,1b]thiazoles under microwave conditions. Synth. Commun.,2001, 31, 1257-1262.

[130] Njoya, Y.; Boufatah, N.; Gellis, A.; Rathelot, P.; Crozet, M. P.; Vanelle, P. Microwave assisted synthesis of new benzimidazoles.Heterocycles, 2002, 57, 1423-1432.

[131] Njoya, Y.; Gellis, A.; Crozet, M. P.; Vanelle, P. Efficient synthesis of new 6-nitrobenzothiazoles using microwave irradiation.Sulfur Lett.2003, 26, 67-75.

[132] Gellis, A.; Boufatah, N.; Vanelle, P. Rapid microwave-promoted synthesis of new sulfonylmethylbenzothiazoles in water.Green Chem., 2006, 8, 483-487.

[133] Kabri, Y.; Gellis, A.; Vanelle, P. Microwave-assisted synthesis in aqueous medium of new quinazoline derivatives as anticancer agent precursors.Green Chem., 2009, 11, 201-208.

[134] Mahesh, M.; Murphy, J. A.; LeStrat, F.; Wessel, H. P. Reduction of arenediazonium salts by tetrakis(dimethylamino)ethylene (TDAE): Efficient formation of products derived from aryl radicals.Beilstein J. Org. Chem.,2009, 5, $\mathrm{N}^{\circ} 1$.

[135] Burkholder, C.; Dolbier, Jr W.R.; Médebielle, M.Tetrakis(dimethylamino)ethylene as a useful reductant of some bromodifluoromethyl heterocycles. Application to the synthesis of new gemdifluorinated heteroarylated compounds.J. Org. Chem.,1998, 63, 5385-5394.

[136] Médebielle, M.; Kato, K.; Dolbier, Jr W.R.Difluoromethylation reactions of ethyl pyruvate with the TDAE - A mild approach to the synthesis of 3,3-difluoro-2-hydroxy-2-methyl-4-oxo-butyric ethyl esters derivatives.Synlett,2002, 1541-1543.

[137] Giuglio-Tonolo, G.; Terme, T.; Médebielle, M.; Vanelle, P.Original reaction of p-nitrobenzyl chloride with aldehydes using tetrakis(dimethylamino)ethylene (TDAE).Tetrahedron Lett., 2003, 44, 6433-6435

[138] Amiri-Attou, O.; Terme, T.; Vanelle, P. Functionalization of 6-nitrobenzo[1,3]dioxole with carbonyl compounds via TDAE methodology.Molecules, 2005, 10, 545-551.

[139] Montana, M.; Terme, T.; Vanelle, P. Original synthesis of oxiranes via TDAE methodology: Reaction of 2,2-dibromomethylquinoxaline with aromatic aldehydes.Tetrahedron Lett.,2005, 46, 8373-8376.

[140] Khoumeri, O.; Montana, M.; Terme, T.; Vanelle, P. First TDAE approach in quinonic series: Synthesis of new 2-substituted 1,4-dimethoxy-9,10-anthraquinones.Tetrahedron,2008, 64, 11237 11242.

[141] Giuglio-Tonolo, G.; Terme, T.; Médebielle, M.; Vanelle, P.Nitrobenzylation of $\alpha$-carbonyl ester derivatives using TDAE approach. Tetrahedron Lett., 2004, 45, 5121-5124. 
[142] Montana, M.; Crozet, M. D.; Castera-Ducros, C.; Terme, T.; Vanelle, P. Rapid synthesis of new azaheterocyclic hydroxymalonate derivatives using TDAE approach. Heterocycles, 2008, 75, 925932.

[143] Juspin, T.; Laget, M.; Terme, T.; Azas, N.; Vanelle, P. TDAE-assisted synthesis of new imidazo[2,1-b]thiazole derivatives as anti-infectious agents.Eur. J. Med. Chem.,2010,45,840-845.

[144] Amiri-Attou, O.; Terme, T.; Vanelle, P.Original and rapid access to new alkaloid analogues of neocryptolepine: Synthesis of substituted 6-methyl-6H-indolo[2,3-b]quinolines via TDAE strategy Synlett, 2005, 3047-3050.

[145] Juspin, T.; Terme, P.; Vanelle, P. TDAE strategy using $\alpha$-diketones: Rapid access to 2,3diphenylquinoline and acenaphtho[1,2-b]quinoline derivatives. Synlett,2009, 1485-1489.

[146] Montana, M.; Terme, T.; Vanelle, P. TDAE-initiated synthesis of oxiranes in heterocyclic series: Reaction of 2-(dibromomethyl)quinoxaline with $\alpha$-dicarbonyl derivatives.Lett. Org. Chem.,2010, 7, 453-456.

\title{
KEYWORDS
}

Anti-infectious agents;Electron transfer reactions; 5-Nitroimidazole; Palladium-catalyzed reactions, VNS reaction.

\begin{abstract}
5-Nitroimidazoles are drugs having both antiprotozoal and antibacterial activity, but show mutagenicity and development of resistance observed particularly with metronidazole. For the development of new potentially safer derivatives, we investigated new strategies of synthesis: such as Vicarious Nucleophilic Substitution of hydrogen (VNS), palladium-catalyzed cross-coupling reactions (Suzuki-Miyaura, Sonogashira...) and electron transfer reactions (Unimolecular Radical Nucleophilic Substitution $\left(\mathrm{S}_{\mathrm{RN}} 1\right)$, TDAE methodology) applied in 5nitroimidazole series.
\end{abstract}

\section{GRAPHICAL ABSTRACT}

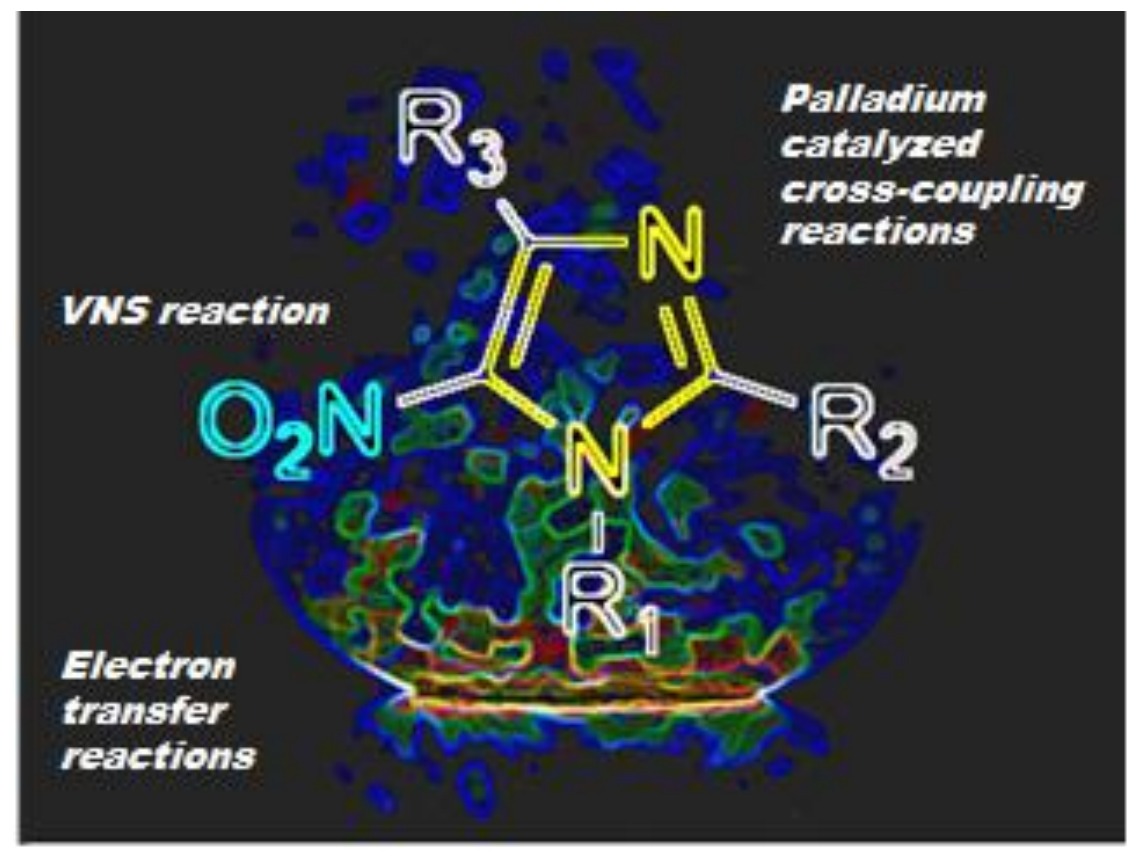

